$\mid \begin{aligned} & \text { UNIVERSITY OF LONDON } \\ & 25\end{aligned} \begin{aligned} & \text { INSTITUTE OF LATIN AMERICAN STUDIES } \\ & \text { RESEARCH PAPERS }\end{aligned}$

Argentina and the
United States

at the

Sixth Pan American

Conference

(Havana 1928)

David Sheinin 



\title{
Argentina and the United States at the Sixth Pan American Conference (Havana 1928)
}

\author{
David Sheinin
}


British Library Cataloguing in Publication Data

A catalogue record for this book is available from the British Library

ISBN $\quad 0-901145-74-2$

ISSN 0957-7947

(C) Institute of Latin American Studies

University of London 1991 


\section{CONTENTS}

I Introduction 1

II United States Preparations for

Havana: Effecting Control 3

III The Conflict at Havana 8

IV Perspectives on the

V Conclusion: Consolidating Control 25

Notes and References 33 
David Sheinin is Assistant Professor of History at Trent University, Peterborough, Ontario. He was an Honorary Research Fellow at the Institute of Latin American Studies, 1990-91. 


\section{Argentina and the United States at the Sixth Pan American Conference (Havana 1928)}

\section{I - Introduction}

In 1928, at the Sixth Pan American Conference (Sixth Conference of American States) in Havana, Argentine delegation chief Honorio Pueyrredón boldly challenged United States military intervention in Latin America and, in a lesser criticism, opposed high US tariff barriers. On 4 February, during a meeting of the conference Committee on Public International Law, Pueyrredón introduced for the first time at a Pan American Conference an open declaration against US military intervention. In support of the Central American nations, Pueyrredón defended the sovereignty of each nation state in the hemisphere: 'diplomatic or armed intervention, whether permanent or temporary', he declared, 'is an attack against the independence of states and is not justified by the duty of protecting nations, as weak nations are, in their turn, unable to exercise such right...."'

Reported in newspapers around the world, Pueyrredón's challenge to the United States' right to intervene in Latin America was explosive. It threatened to embroil the Pan American Union in an issue which, until 1928, had been the exclusive concern of the United States and the individual nations occupied by US expeditionary forces. ${ }^{2}$ The Argentine delegation chief raised the antiintervention issue at a time when policy-makers in Washington felt their diplomatic stand on military intercession was dangerously prone to criticism from abroad. The Sixth Pan American Conference began during an escalation of United States military activity in Nicaragua; through late 1927 and early 1928, United States Marine units made new forays into territory held by Augusto Sandino, in search of the rebel leader's base camp. At the same time, throughout the hemisphere, public condemnations by politicians, journalists, and others mounted. The State Department felt precariously exposed. ${ }^{3}$

Since the Havana Conference, taking account of these public condemnations of US military adventurism, the historical literature in both Argentina and the United States has portrayed the confrontation that followed Pueyrredón's comments in terms limited by official statements and press reports. Immediately after the meeting, newspapers in tens of countries, many Argentine leaders, and the United States Department of State adopted a version of events holding that Pueyrredón offered a strong Argentine challenge to US interests in Latin America. This challenge placed in jeopardy United States foreign policy objectives for the hemisphere, and ran the risk of marshalling widespread Latin American political opposition to US military activity in 
Central America. Until now, much of the historical literature on the clash has posited that the United States countered the anti-interventionist challenge through the diplomacy of United States delegation chief and former Secretary of State Charles Evans Hughes. The historian Samuel Flagg Bemis and others have reasoned that, by means of his outstanding diplomatic skills, Hughes garnered sufficient diplomatic support at Havana to defeat the attack and the risk to United States interests in Latin America. ${ }^{4}$

The Hughes versus Pueyrredón equation of conflict, as documented in the majority of historical works on the Sixth Conference, addresses an important diplomatic facet of Argentine-United States relations and Pan American interactions in the late 1920s. In the sections that follow, this study will recast the equation to suggest a broader scope to the problem of United StatesArgentine conflict at Havana. Section II, 'United States Preparations for Havana: Effecting Control', challenges the State Department version of Hughes's diplomatic triumph. It proposes that, while the diplomacy of the United States delegation chief proved essential to US control at the Pan American assembly, Hughes did not arrive at the gathering, as the State Department maintained publicly, with nothing but his diplomatic abilities to confront and defeat anti-intervention. Without the knowledge of the public, the international press, and most delegates, Hughes reached Havana after months of State Department preparation that won promises from most Latin American states not to contradict United States policy. In addition, despite the ostensibly open and democratic functioning of the Pan American Union, Washington adopted a determined strategy to suppress discussion of any topic the United States government deemed controversial.

United States officials were unable to master complete control of the conference agenda, but gained strong support for their positions. This drive for authority reveals three notable features of US expansionism in the late 1920s. First, in spite of the hegemonic influence the United States enjoyed in much of Latin America, authorities in Washington feared the implications of a South American diplomatic challenge to US military activity in Central America. Second, the US tactic of approaching individual nations for support, while keeping each country's leaders unaware of equivalent backing garnered elsewhere in the Americas, marked the first extensive use of a control method the United States would apply successfully at later Pan American and Organisation of American States meetings, including the Pan American Union Foreign Ministers' Meetings during World War II and the 1954 Caracas Conference. Third, the lead-up to Havana provides stark evidence for a unity of purpose and method in United States imperialism in Latin America. Although the United States sent no Marines and established no military administrations south of the Caribbean basin, the Havana preparations show that Washington could not divorce unrest in Central America from its relations with the South American countries. Moreover, while strategies varied from nation to nation, the United States sought short- and long-term ends in Latin America through methods and tactics that stressed overriding control. 
Section III, 'The Conflict at Havana', explores the Argentine challenge and the United States response. It argues that in its final form, Honorio Pueyrredón's stand on United States military activity in Nicaragua and, secondarily, on high US tariff walls, reflected the personal and politically-motivated action of one individual. It did not represent Argentine government policy on antiimperialism, opposition to US militarism, solidarity with neighbouring Latin American states, or anger over US trade policies, though elements of each of these factors were manifest in Argentine politics. Pueyrredón's failure, and his eventual censure and removal as delegation chief by the Argentine government, contrasts the disorder and weakness of Argentine international influence with the successful United States exercise of control.

Section IV, 'Perspectives on the Argentine Challenge', interprets Pueyrredón's actions in the context of domestic political issues (in particular, the weakness of President Marcelo T. de Alvear), the delegation chief's ministerial aspirations, and tacit Argentine support in advance of the Havana Conference for the United States position on Nicaragua. Section V, 'Conclusion: Consolidating Control', frames the Havana Conference between earlier efforts by Washington to exert authority within the Pan American Union, the accompanying rise of US economic influence in Argentina and other Latin America states, and the short-lived consolidation of US dominance after the Sixth meeting - at the 1928-1929 Washington Conference on Conciliation and Arbitration. This section contemplates the collapse of that supremacy with the onset of the Great Depression and the emboldened anti-interventionism of Latin American delegates to the Seventh Conference of American States in 1933.

\section{II - United States Preparations for Havana: Effecting Control}

In 1928, at Havana, the United States backed an agenda that stressed economic questions, including maritime neutrality, simplification of consular procedures, regulation of rail traffic, and agricultural cooperation. Yet, in its preparations for the conference, the US government was concerned principally that some nations might introduce controversial topics for discussion. Secretary of State Frank B. Kellogg called for their suppression. The Secretary singled out the danger of an anti-imperialist statement at Havana. During the preceding year, anti-US propaganda had escalated throughout the hemisphere. While United States military and political intervention in Central American predated the First World War, extensive Latin American opposition to these incursions began only during the 1920s. Popular outcries scorned a series of United States interventionist tactics in Nicaragua that seemed to threaten the security of all nations in the hemisphere.

When the Conservative former president Emiliano Chamorro lost the 1924 Nicaraguan general election, he staged a coup that launched the nation into civil war for the remainder of the decade, as the ousted vice-president, Juan B. 
Sacasa, mounted an armed struggle to regain the government. The United States responded with a new landing of Marines, which suppressed the fighting and oversaw a coup d'état by the conservative general, Adolfo Díaz, in late 1926. After the United States recognised the illegitimate usurper, most of Sacasa's officers ceased combat. One exception was General Augusto Sandino, whose armed resistance to the US military presence inspired criticism of the United States throughout Latin America, sparking Kellogg's fears in 1927. Between May 1927 and March 1928, forty-one US warships regularly patrolled Nicaraguan waters. Over roughly the same period, the United States government spent some $\$ 3.5$ million on military operations in Nicaragua. ${ }^{5}$

In the United States, as in Latin America, 1927 brought public reassessments of the US role in Latin America that troubled Secretary Kellogg and other State Department officials. Writing in the periodical Foreign Affairs, the political commentator Walter Lippman called for a new policy towards Latin America 'as momentous as the Monroe Doctrine itself'. The conflict precipitating this need for review was what Lippman contrasted as 'the vested rights of [North] Americans in the natural resources of the Caribbean countries and the rising nationalism of their peoples'. In an analysis that highlighted the exacerbation of the crisis, as he described it, and Kellogg's growing preoccupation with Nicaragua, Lippman noted that this 'problem could not have arisen before [North] Americans had acquired titles to important properties and had invested large sums of money developing them; nor... while government of these countries was in the hands of a ruling class which conceived its interests to be those of the foreign owners...' Lippman attacked the fallacies of United States military intervention and the Monroe Doctrine itself (a foreign policy mechanism that Kellogg insisted be upheld rigorously by US delegates at Havana); the United States government had reached a stage where not only could European intervention in the event of Latin American political disorder not be tolerated, but political disorder itself could not be allowed. 'From this point it was but a short step to the theory that the United States must insure itself in the Caribbean region against supposedly unfriendly governments. ${ }^{6}$

Kellogg's reputation as a red-baiting anti-Bolshevist received more direct criticism in the United States Congress. When the Secretary issued the document 'Bolshevik Aims and Policies in Latin America', outlining a purported Soviet conspiracy in Mexico and Nicaragua, both he and President Calvin Coolidge were called before the Senate Foreign Relations Committee (in January 1927). Senators chided Kellogg for his scanty evidence of a Bolshevik threat. A number of congressmen were equally critical; Representative Ralph F. Lozier argued to his colleagues that Kellogg's efforts 'to link the Government of Mexico with the Bolshevik regime in Russia is both amazing and ridiculous'. 'We should not use our Army and Navy', Lozier reasoned, 'to fight their [Central American] battles'. Representative George Huddleston reported his dismay that Coolidge had intervened in Nicaragua 'for the purpose of establishing the particular government that happens to satisfy him....? 
By mid-1927, Kellogg felt embattled by the denunciations of his policies on Central America, both at home and abroad. By some accounts, he showed signs of exhaustion in early $1928 .^{8}$ His solution, with regard to Havana, was to attempt an unprecedented control of conference proceedings. Were Latin American delegates at Havana to criticise the United States military presence in Nicaragua, Kellogg recommended that the complainants be silenced. 'Every effort', wrote the secretary, 'should be made to have the topics discussed at the Conference confined to those on the pre-arranged agenda, or such additional topics as do not involve any discussion or criticism of the foreign policy of this or any other country.' During 1927, increasingly sensitive to attacks against its Latin America policy, the United States prepared extensively for the Havana Conference. Argentina was one of several countries in which the State Department identified dangerous anti-US activity. A First Bank of Boston official described a growing Argentine fixation on United States intervention in Mexico and Nicaragua and observed, 'it is impossible to remove from the Latin American mind the idea of the Great North American Octopus, spreading its tentacles all over Latin America'. The United States government suspected what its representatives called Bolsheviks, Communists, and Anarchists as the organisers of anti-US criticisms in Argentina and elsewhere. Leaders in the United States were distressed as well about Mexican, British, and Japanese government support for anti-US propaganda in Buenos Aires and the potentially negative effect such activity might have on United States commerce. ${ }^{9}$

The United States focused much of its attention on a pan-hemispheric organisation identified as posing a significant threat to United States diplomatic authority, and as a propaganda vehicle of the Soviet Union. The full danger (as US leaders perceived it) of the Anti-Imperialistic League (a transnational body with headquarters in Mexico City, Buenos Aires, and other Latin American capitals), and its associations with the Soviet Union, had become apparent in Washington only months before the Havana Conference. The League's objectives included the liberation of the US colonial possessions Puerto Rico and the Philippines, the removal of US troops from Haiti and Nicaragua, as well as a US military withdrawal from Panama. Through several wellcirculating publications, and with the backing of Diego Rivera and other prominent Latin American anti-imperialists, the organisation's leaders were spreading their arguments and gaining adherents from Mexico to Chile. ${ }^{10}$

US diplomats conveyed data to Washington on Communist and AntiImperialistic League activities throughout the Americas. In early 1928, the State Department found evidence of fierce anti-US propaganda in Uruguay and Guatemala. In Argentina, the United States Ambassador reported the formation of a new organisation critical of the 'unjustified and unspeakable Yankee invasion of Nicaragua' - the Liga Pro Unión Americana. When the group mounted a protest in front of the Bank of Boston Building in Buenos Aires, Robert Woods Bliss protested to the Argentine Foreign Relations Ministry. Socialist politician Alfredo L. Palacios, another outspoken critic of imperialism in the months before Havana, lamented publicly that 'when the bankers were 
British, the Monroe Doctrine defended us. But who will defend us today from the grandchildren of Monroe?' Palacios criticised the Pan American Union as a 'faithful instrument' of imperialism. "

United States officials were troubled further by mainstream Argentine political opposition to the US military presence in Nicaragua. In mid-1927, responding to congressional pressures, the President of the Argentine Senate acted on a resolution calling Foreign Minister Angel P. Gallardo before that body. Leopoldo Melo invited Gallardo to explain the Executive office position on the US intervention in Nicaragua; the Foreign Ministry demurred and congressional rebukes carried on unabated. Argentine press reports in the weeks before the conference were replete with criticisms of United States military intervention in Nicaragua. Jorge Mitre, publisher of the generally proUS La Nación, and regarded in Washington as an ally of the United States, denounced the foreign military actions in Nicaragua; they represented a 'test' of Pan Americanism, he asserted, and the Latin American states were entitled to an 'explanation' from the United States. The newspaper La Razón distinguished between the supposed idealism of Woodrow Wilson's foreign policy and United States aggressiveness in Central America: 'greatness and power are dis-Americanising the United States. This refers to the barbarous kick administered Sandino - the fatherland of Wilson making war against a petty leader of Central America!'12

Responding to these and other foreboding signs of Latin American discontent, and what Kellogg believed were Communist pressures, the State Department prepared for Havana by warning its diplomats of an impending anti-US attack. Secretary Kellogg instructed United States Legations to gather information on the likelihood of each nation's participating in such a confrontation. The State Department also asked that governments be canvassed for their blanket support of US positions at Havana. ${ }^{13}$ Kellogg was openly antagonistic towards Latin American sensibilities over United States imperialism. In November 1927, he wrote to Robert Woods Bliss that Mexican criticisms of United States foreign policy were no more than the jealousy of a nation that lacked the power and influence of Washington. Not being able to afford the 'protection that one sovereign nation is entitled to demand from another', the Mexicans waxed bitter at the US ability to do so. Kellogg bullishly insisted on the positive United States record in Mexico:

If I had the time, I could justify every act we have performed; in fact, we have been patient beyond any degree to which we would ordinarily be with a more responsible government. The same is true as to Central American countries. The United States has no desire to dominate them, as you know but it is hard to make these countries realise that we are not imperialistic and ambitious. ${ }^{14}$

Assistant Secretary of State Francis White warned US diplomats that some delegates might try to inject into the Conference controversial subjects and 
matters of a political nature which this Government feels do not properly belong on the agenda of a Pan American Conference, and do not promote the best interests of Pan-Americanism'. The State Department wished to know how delegates from each country would respond to such potentially sudden diplomatic manoeuvres once the conference began. ${ }^{15}$

As the conference approached, the State Department received more galling evidence of a coming challenge to United States authority in Latin America. The US ambassador in Uruguay learned that the Cuban government was apprehensive that 'certain political questions' might be brought before the conference, at the instigation of the Mexican government. The Cubans wished to avoid controversy. 'I was convinced', wrote Ulysses Grant-Smith, of the Cuban diplomat who disclosed the information, 'that he had full knowledge of the matter but the most that I could extract from him was that he thought that its purport was anti-Yankee.' At the end of 1927, Grant-Smith sounded the alarm again in a terse telegram. He reported from Montevideo that the Mexicans and other Latin American governments planned to introduce a formal agreement at Havana by which no state would be permitted to intervene in the affairs of another. ${ }^{16}$

US diplomats followed the State Department's instructions to counter possible antagonism to US foreign policy. During the last three months of 1927, they gained the adherence of a majority of Pan American Union member governments to bolster US conference measures. The Peruvian government gave the United States assurances that their delegates would support the United States without fail. The US Minister in Tegucigalpa, George T. Summerlin, relayed to Kellogg that he had 'good reason to believe' that the Hondurans would be instructed to 'entertain views similar to those of the delegates of the United States'. The Guatemalan, Haitian, Colombian, Dominican, Nicaraguan, Costa Rican, Brazilian, Salvadoran, Venezuelan, and Bolivian governments proffered similar assurances. Although Chile did not give an ironclad guarantee of support, the US Chargé d'Affaires in Santiago correctly predicted that the Chilean delegates would not contradict the United States at Havana. ${ }^{17}$ Months before, the State Department had ensured the cooperation of the host country. In April 1927, the chief of the Division of Latin American Affairs travelled with the President of Cuba on the train from Key West to Washington. Stokeley W. Morgan asked Gerardo Machado what the latter anticipated at the Havana Conference:

I reminded him that a certain tendency to inject controversial political subjects into the discussions had become apparent in Santiago in 1923 and that it was not impossible that this tendency might be even more marked in Habana next year. The President said he realised that fact and was taking steps to guard against any injection of undesirable matter into the discussions. The control of this he said rested entirely with the President of the Conference. ${ }^{18}$ 
The Cuban president of the Conference, Antonio Sánchez de Bustamante, would have strict instructions from Gerardo Machado not to permit the discussion of subjects embarrassing to the United States.

The State Department also received a promise from Angel Gallardo that Argentina was opposed to the introduction of controversial themes. Ambassador Bliss was confident enough about the pro-US positions of delegates Honorio Pueyrredón and Felipe Espil that he reported it unnecessary to submit detailed reports on the two diplomats. The Argentine representative who most perplexed Bliss was Laurentino Olascoaga, who had suggested the formation of an ill-defined 'League Between the States of South America'. The Argentine delegate was an unknown quantity, but US leaders believed they could manipulate him: ${ }^{19}$

[He] is somewhat ridiculed because of affecting the tonsorial style of colonial days and cultivating a resemblance to General San Martín. His influence in the Argentine delegation will be very secondary to that of Ambassador Pueyrredón and Dr. Espil.... He is, however, worth cultivating and is not adverse to flattery. ${ }^{20}$

Bliss confirmed that the Argentine government had selected its delegation with the provision that it work 'in complete understanding' with the United States. The Argentine Foreign Ministry informed Bliss that Pueyrredón had been instructed specifically not to discuss contentious subjects or any themes not itemised in the pre-arranged agenda. The contradiction between this assurance and the Argentine delegation chief's eventual outburst underlined the absence of a resolute Argentine conference agenda, comparable to that of the United States. It also showed that the 'ironclad' guarantees of support that Secretary Kellogg sought, and believed he had won, in advance of the Havana Conference, were not, in fact, ironclad.

\section{III - The Conflict at Havana}

Delegates arrived at Havana to address problems in three broad areas: the organisation of the Pan American Union, the codification and adoption of a treaty of public and private international law, and social and economic problems of common interest in the Americas. Conferees conducted their work in committees composed of one or more representatives and technical assistants from each state. As preparations for the gathering were completed, Argentine authorities tempered assurances of support for the United States with a lastminute agenda change. Early in January 1928, Gallardo had confirmed to the press his government's intention not to raise the cause of Nicaraguan sovereignty at Havana. Speaking to reporters in Paris, he adopted the US maxim of strict adherence to the pre-conference agenda (which did not include a discussion of the United States presence in Central America). He explained, 'the Nicaragua problem is not on the agenda [of the Havana Conference] and 
since it is not on the list of subjects to be treated I do not think it will come up'. But in the international climate of growing hostility to United States military interventions abroad, the Argentine government decided it did not wish to be publicly identified with Yankee imperialism. ${ }^{21}$

The Foreign Ministry prepared a new plan, in the event an anti-intervention motion were introduced. On 13 January, three days before the conference opened, the Foreign Ministry sent Argentine delegates modified instructions. Were another delegation to introduce a Nicaraguan resolution, the Argentine government wished to adopt a timid, but clearly stated supportive position. Acting Foreign Minister Antonio Sagarna ordered delegation chief Pueyrredón to choose an opportune moment to argue for the sovereignty of states and their interdependence, without openly confronting the United States. Should the opportunity arise, the Foreign Ministry wished to offer a non-committal voice of support to its sister Latin American republics - "sin entrar a juzgar el estado de las relaciones jurídicas entre los Estados Unidos de América y Nicaragua'. ${ }^{22}$

Five days later the Foreign Ministry moved still farther from its guarantee of support to the United States. The change was perhaps in response to the Buenos Aires press corps, whose rebukes of Argentina's failure to define a forceful pre-conference position on Nicaragua were mounting. More likely, the Foreign Ministry had begun to anticipate what the State Department had seen for months as imminent. In that a confrontation over US military intervention in Central America was a virtual certainty, Argentina might effect a diplomatic coup by being the first to raise objections. Yet, if worded carefully, the grievance might be ambiguous enough to avoid alienating the United States; by opposing intervention while offering a broad-based endorsement of US economic resolutions, the Argentines might remain true to the spirit, if not to the letter, of their promise to back the United States on all issues. On 18 January, Sagarna asked whether Pueyrredón thought it advantageous for Argentina to take the initiative on anti-intervention. Sagarna wanted Pueyrredón's opinion on an independent Argentine statement at the conference, supporting Nicaragua, but not openly bellicose towards the United States. ${ }^{23}$

On 26 January, Pueyrredón responded to Sagarna's instructions, setting the stage for his conference stance on US military aggression. He did not answer Sagarna directly, but informed the Foreign Ministry that he expected an opportunity for an Argentine initiative on Nicaragua. Pueyrredón wrote that he would issue the declarations the Foreign Ministry called for at conference discussions on the rights of sovereign states. In the tenacity of his stand, however, Pueyrredón planned to manipulate the Foreign Ministry's intent into a personal political gambit. ${ }^{24}$

As the conference opened, the United States remained unable to calculate precisely how, or from what quarters, an attack on military intervention might be launched. This was scarcely surprising. The State Department had accurate 
information on mounting Latin American anti-imperialist sentiment, but erred in its suspicions of possible collusion and conspiracy among nations. Kellogg anticipated incorrectly that an attack against the United States had been thought-out by one or more nations long in advance of the Sixth Pan American Conference. On the contrary, both Pueyrredón's challenge and a similar criticism by Salvadoran delegate Gustavo Guerrero were made against stated Argentine and Salvadoran government policies. Nevertheless, the United States was prepared for a carefully planned, open diplomatic revolt within the Pan American Union.

Following US conference objectives of commercial normalisation, the Public International Law Committee was formed to determine means of implementing a vast body of existing international agreements. The ponente ${ }^{25}$ of the committee was Dr. Víctor Maúrtua of Peru. Maúrtua's allegiance to the United States led to an interpretation of international law which other delegates found cavalier and menacing - and which formed the backdrop to Pueyrredón's 4 February critique of diplomatic and armed intervention. Conference participants were surprised when Maúrtua tried to couch the committee's consideration of international relations in nothing more than a vague declaration of principles. This would serve supposedly as the basis for future legal codification. In practical terms, an imprecise agenda would limit the debate on United States intervention in Central America. Maúrtua put forward his concept of an interdependence of nations. He argued this principle before committee delegates, insisting that an absolute independence of nations could not exist. ${ }^{26}$

The implication of the ponente's reasoning was that Nicaragua and other nations could not expect outright independence, as defined in the antiimperialist arguments of some delegates. Many participants immediately derided Maúrtua's contention as unacceptably open to a broad range of interpretations - precisely the ambiguity sought by the United States. The committee broke down into two competing camps. Those opposing the ponente favoured a formal codification of international law and, in principle, Pueyrredón's critique of United States military interventions. At first, they included Guatemala, the Dominican Republic, Argentina, Honduras, Mexico, El Salvador, Colombia, Ecuador, Paraguay, Haiti, and Panama. The United States, Cuba, and Nicaragua backed Maúrtua's interpretations while Brazil, Chile, Uruguay, Costa Rica, Venezuela and Bolivia expressed neutral positions. A sub-committee was formed to try to accommodate the opposing viewpoints. It failed to do so and as a result, the problem was postponed to discussion at a later date. This represented Charles Evans Hughes's first diplomatic victory at the conference; the former Secretary of State, a member of the conciliatory subcommittee, worked not to win over other delegates to Maúrtua's viewpoint, but to forestall a consensus in favour of formal codification. For the United States, adjournment represented victory. It accomplished the defeat of anti-interventionist sentiment, without the adverse publicity of a drawn-out diplomatic confrontation at Havana. ${ }^{27}$ 
In itself, and in light of the open-ended instructions Pueyrredón received in the days before the conference began, the Argentine anti-intervention motion did not contradict Foreign Ministry instructions, nor did it follow government policy. Whether the Argentine delegation chief could have won sufficient backing for a codification of anti-intervention remains uncertain; because he contradicted Argentine government policy on economic cooperation with the United States, Pueyrredón was removed from his conference post. Because they forced Pueyrredón's resignation as delegation chief, Argentine authorities undercut their nation's leadership role at Havana on the intervention issue. On 23 January, twelve days before his objection to United States military interference in Latin America, Pueyrredón directly defied Argentine government policy and a history of Argentine support for United States economic goals within the Pan American Union. He refused to sign a conference convention on the reorganisation of the Pan American Union without the inclusion of a preamble critical of high tariff barriers. The United States correctly interpreted the refusal as a denunciation of US tariffs. And although they responded belatedly, Pueyrredón's superiors refused to allow the tariff criticism to stand.

In his statement on tariffs, Pueyrredón insisted that high trade barriers to which he objected constituted an infringement on economic cooperation among nation states, an essential component of Pan Americanism. In addition, Pueyrredón made reference to what he felt had been an arbitrary 1927 sanitary ban by the United States against Argentine cattle; he called for a rule guaranteeing that plant or animal quarantines would not be effected arbitrarily. Despite the fact that over the preceding year the sanitary ban had been at the forefront of Argentine political discussion, United States officials ignored this latter feature of Pueyrredón's reproach. The Argentine delegation chief himself did not raise the sanitary ban issue again at the conference. ${ }^{28}$

More generally, Pueyrredón's attack on high tariffs was poorly conceived. Enacted by a Republican-dominated Congress and against the wishes of the outgoing Woodrow Wilson administration, the Emergency Tariff Act of 1921 and the Fordney-McCumber Tariff Act of 1922 prompted stormy protests in Argentina against prohibitive rates on such vital Argentine exports as wheat, corn, wool, meat, sugar, and hides. Before passage of the Emergency Tariff Act, of twenty key commodities that comprised $80 \%$ of Argentine exports to the United States, fifteen entered the United States free of duty. After 1921, only two of those items could be imported without a duty charge. Argentine criticisms of the United States rates persisted through the 1920s, however the government of Marcelo T. de Alvear had no interest in pursuing Pueyrredón's tariff-based antagonism; Argentine rates were as high or higher than their US equivalents and subject to criticism from other Latin American nations. In $1926,31.7 \%$ of Argentine imports to the United States entered duty-free while only $27.2 \%$ of goods from the United States to Argentina were free of tariff charges. United States tariff rates were generally lower than those of Argentina, but the average United States rates on imports from Argentina were 
higher than the Argentine rates on shipments from the United States - this latter statistic was the result of the high US barriers on flaxseed and wool, from which most of the revenue from Argentine trade with the United States came. $^{29}$

Pueyrredón resigned, as a result of his conflict with the Argentine government over the tariff issue, but not before having merged, by virtue of his actions, two previously independent areas of Argentine foreign policy economic relations with the United States and a public defence of national selfdetermination rights in the Americas. For the Argentine government, alarm over Pueyrredón's alienation of the United States on the tariff criticism precluded taking the measured diplomatic stand on intervention that Sagarna had contemplated; in the final days of the conference, Argentine representatives were instructed not to take any actions that might alienate the United States. For Washington, concerns over anti-intervention became compounded suddenly with what was seen as unprecedented and unexpected Argentine belligerence with regard to questions of trade.

Initially it seemed that the Argentine government would back Pueyrredón's renegade stance. On 24 January, the day after the delegation chief made his remarks on tariff walls, the Foreign Ministry in Buenos Aires sent Pueyrredón a congratulatory telegram. It was not until 10 February that Felipe Espil took the unusual step of denouncing his superior to the Argentine Foreign Ministry. ${ }^{30}$ Only after Espil's 10 February communication did President Alvear order Pueyrredón to sign the document. A day later, the delegation chief answered by brazenly summarising his objections to the US tariffs. He made no commitment to signing the conference convention. At this point, the State Department was as concerned as Espil with Pueyrredón's intransigence. But on the same day that Espil sent his telegram to Buenos Aires, Ambassador Robert Woods Bliss satisfied the State Department that the Argentine government would censure Pueyrredón. The US ambassador learned from a reliable source that matters would be 'straightened out in the Argentine delegation'. Bliss informed Washington that there was no need for the United States to 'force matters too strongly'. Yet Pueyrredón's tone remained belligerent. He suggested to the Argentine President that his signing the convention was out of the question. Having expressed a strong opinion on the matter, the delegation chief believed that he could not now reverse his stand. Pueyrredón suggested a face-saving compromise to Alvear. The delegation chief might reject the document at Havana, but pass it on to the government in Buenos Aires for ratification. ${ }^{31}$

By 12 February, Pueyrredón had received no further instructions pursuant to his latest suggestion. When the press learned of Alvear's insistence that Pueyrredón back down from his attack on the United States, the delegation chief sent another telegram to Buenos Aires. He informed the administration that Alvear's order to sign the document was embarrassing him. Now openly insubordinate, Pueyrredón brashly announced that if he did not to receive 
further instructions by noon on 13 February, he would publicly restate his insistence on an anti-tariff clause. The Argentine government received the telegram the morning of the threatened deadline. Within hours, the Foreign Ministry shot back a response, which was delivered to the delegation chief at 9:40 a.m. The Foreign Ministry instructed Pueyrredón not to attend a meeting of the delegates scheduled for that afternoon. Pueyrredón disobeyed and attended the meeting, reaffirming that he would not sign the conference document. Later, he informed the Foreign Ministry that its telegram had not reached him in time. ${ }^{32}$

Foreign Minister Gallardo responded on 14 February. He criticised Pueyrredón for having disobeyed instructions and, in the process, having defined an extremist position for Argentina. Gallardo defended Pan Americanism as well as Pueyrredón's concept of a tariff-free zone in the western hemisphere. But he reviled what he sensed was the political intent of his subordinate. The State Department remained uncertain whether or not Pueyrredón expressed the views of his government. Bliss suspected correctly that the Foreign Ministry had deliberately concealed the full extent of the Pueyrredón-Gallardo split. The Argentine authorities were embarrassed at the strong views Pueyrredón had issued on behalf of his government. Also, Gallardo did not wish to reveal other sensitive political problems that Pueyrredón raised through his statements. Argentine politicians feared that their leadership on a non-intervention platform might precipitate negative publicity for the federal government's many interventions in the governing of the Argentine provinces since the first presidential administration of Hipólito Yrigoyen. ${ }^{33}$

In a final effort to convince Pueyrredón not to disrupt Argentine conference objectives, Gallardo demonstrated his government's continued willingness to place Argentina at the head of an anti-intervention motion under two conditions - the backing of a majority of Latin American delegates and the likelihood of the motion being passed. The Foreign Minister responded to Pueyrredón's argument that to accept the Pan American Union reorganisation document without a statement on high tariffs would constitute unacceptable ambiguity on the part of Argentina. On 15 February, Gallardo suggested that it was by not taking an extreme position on the issue of tariffs ("en no extremar la intransigencia en el asunto arancelario') that the Argentines might then be 'entirely intransigent' on foreign interventions. Gallardo recommended that Pueyrredón defer the question of the Pan American reorganisation not on the basis of tariffs, a proposition on which the Argentines stood alone, but over antiintervention for which Argentina could count on considerable support from Latin American colleagues. Were the Argentine delegation to follow this course, the Foreign Minister pointed out, 'in case of the worst', the Pan American Union would appear to fail because of 'North American intransigence on the question of intervention and not for Argentine obstinacy on the problem of tariffs, of lesser importance'. ${ }^{34}$ 
As well as policy logic, the Foreign Minister offered Pueyrredón a facesaving exit. He urged that the delegation chief adopt a tactic used before at international gatherings. Pueyrredón could sign the document while issuing a public reservation on the question of international trade. The problem could be set aside for a future debate. Pueyrredón remained firm. Responding to Gallardo's effort at reconciliation, the delegation chief defended the legitimacy of his actions. If the Foreign Ministry objected to his statements, those objections should have been explicitly stated when he made his initial speeches at the conference. ${ }^{35}$

Pueyrredón could not back down. To have done so would not only have weakened his reputation as a diplomat, but would have jeopardised political ambitions he held. He refused to sign the convention and resigned both as delegation chief and Ambassador to the United States. In the hope of maintaining an image of government unity, Alvear rejected the resignation and now authorised Pueyrredón to withhold his signature from the reorganisation document; the Argentine government could approve the convention at a later date, as Pueyrredón had proposed before. On 16 February, Pueyrredón advised the Foreign Ministry that his resignation would stand. He insisted, in his formal communication, that the question was not simply one of his personal standing, but of how the Argentine government perceived Pan Americanism. Pueyrredón argued that his stance was based on an understanding that the hemisphere's economic problems must take precedence in Pan Americanism. His resignation derived from Alvear's failure to concur. Pueyrredón forced his government's hand by leaking details of his resignation to the press. This time, the government accepted his departure.

Only twenty-four hours after Gallardo had suggested that Pueyrredón abandon tariffs in favour of anti-intervention, as a point of principle, and on the day Pueyrredón resigned, delegate Olascoaga notified Gallardo that his conference colleagues on the Committee of Public International Law had not been able to reach agreement on anti-intervention. They had begun to discuss the suggestion that the problem be postponed to a future conference. Olascoaga asked the Foreign Minister whether the Argentine delegation should accept the deferment. Gallardo replied that Olascoaga was to make Argentina's objections to intervention known in a brief statement, but if the majority resolve to postpone the issue to the next conference you are to submit to the majority resolution'. With the Alvear administration preoccupied over Pueyrredón's misrepresentation of Argentina's policy on US tariffs, and with Pueyrredón's dispute with his government exposed in the international press, Argentina's conference leadership collapsed; the opportunity for an Argentine-directed antiintervention challenge was lost. ${ }^{36}$

Once Pueyrredón resigned, the Argentine delegation acquiesced to United States foreign policy objectives. On the questions of commercial arbitration, the creation of facilities for international money orders, the regulation of hydraulic power, and other problems in the normalisation of trade and finance, 
the Argentine Foreign Ministry simply instructed its delegates to 'keep in mind' international agreements which might take precedence over a Pan American document. Otherwise, Felipe Espil and his colleagues were to maintain the supportive stance originally promised to Washington. Argentina backed pre-set discussion on a variety of trade and finance propositions, including international automobile traffic, the establishment of international shipping lines, and the exchange of scientific information. Delegates passed resolutions on several important trade-related themes including the convocation of a special conference to study the problems of trademark protection, on the simplification of consular procedure, and for the construction of a Pan American highway. Diplomats present adopted and signed a convention regulating serial navigation, and resolutions forecasting the completion of the Pan American Railway - two thirds of which had been constructed already, and which when completed would connect New York and all other cities of the United States with Buenos Aires and Santiago. ${ }^{37}$

The threat to US authority at Havana, however, did not end with Pueyrredón's departure. Delegates to the Committee on Public International Law had agreed to postpone the question of anti-intervention to the Seventh Pan American Conference. But when, on 18 February, the issue came up for confirmation during the final plenary session, the new Argentine delegation leader, Laurentino Olascoaga, introduced a resolution expressing the regret of his Government that the conference had not been able to accomplish anything on the topic of intervention. ${ }^{38}$ A number of other delegates went through the same formality and finally all delegations, including that of the United States, expressed their regret that no solution had been found on the matter. The Guatemalan delegate, Alvarado Tello, then moved the conference to a revival of the anti-intervention conflict by formally asking the Committee on Public International Law why it had been unable to propose a solution when it seemed all delegates were 'in agreement' on the issue. In fact, the delegates agreed only on their expression of regret. Nevertheless, the Guatemalan's interjection allowed Gustavo Guerrero another opportunity to criticise US policy in Central America. He proposed that the conference go on record as opposed to intervention. ${ }^{39}$

During this final important gathering of the conference, in the midst of a torrent of anti-US cat-calls from the press gallery, Hughes drew on the support Kellogg had garnered in late 1927. The US delegates benefited from a curious break in proceedings; immediately following Guerrero's interjection, Cuban university dignitaries entered the hall to deliver official closing speeches for the conference. As the speeches were delivered, Hughes approached allies among the Latin American delegates. He told Raúl Fernandes of Brazil and Enrique Olaya Herrera of Colombia that he could not 'be put in the position of stopping discussion on the matter'. He sent word to the Cuban conference chair, Antonio Sánchez de Bustamante, that on no account should the session be adjourned until the matter were resolved favourably for the United States. Once the university officials had left the hall, Hughes's Latin American 
supporters responded to Guerrero. Fernandes made a speech critical of the Salvadoran and was supported by the Colombian and Costa Rican delegations. Understanding that his own commentary would be necessary to quell this final challenge, Hughes then rose to defend the Latin America policies of the United States after which he was applauded loudly from the floor. Guerrero withdrew his proposal. Before the committee's report postponing the intervention problem was adopted unanimously, Víctor Maúrtua reassumed his defence of US interests. In a fiery speech he charged Guerrero with coming to Havana to play politics, and to bring about disorder, disorganisation, and 'jungle life'. ${ }^{40}$

Long prior to this last anti-intervention discussion at Havana, Felipe Espil emerged as a key conference leader, guiding the crucial sixth committee, charged with economic problems. Delegates also assigned Espil to study methods for the implementation of trade mark rules. Conference minutes described Espil's report to the delegates as 'brilliant'. A devoted exponent of uniformity in trade and finance, Espil proved an ardent supporter of the US goal of commercial normalisation. At Havana, he chastised his colleagues for not having reached an accord on the uniformity of trade mark rules before 1928. Earlier resolutions for such regulations had been ratified by only a few member nations. Part of the problem, according to Espil, was that the Pan American conferences were not the ideal media for this kind of discussion. Real progress could only be achieved, he advocated, at more specialised international meetings. Espil called for regular Pan American reunions on particular obstacles to trade and finance. ${ }^{41}$ He identified with the US characterisation of Pan Americanism as a vehicle for greater commercial stability. This accounted for the disdain he showed towards Pueyrredón's demagogy. Espil believed that the United States objective of protecting industrial property through tariffs would benefit all nations of the hemisphere. Regulation would provide security for both consumers and producers, thereby allowing for economic growth on a US model. Delegates to the Sixth Pan American Conference eventually drafted and signed eleven conventions, sixtytwo resolutions, seven motions, and four agreements; the vast majority of these dictated and modified rules of trade and finance among participatory states. After Pueyrredón's departure, Argentina proved a staunch supporter of United States economic policy at the gathering. ${ }^{42}$

In the final days of the Sixth Pan American Conference, with Espil manoeuvring a realignment of the Argentine position to conform with past adherence to United States economic policy, Pueyrredón attempted to reaffirm his past diplomatic relations with the State Department. Having returned to Washington, Pueyrredón visited Secretary Kellogg to insist that his comments on high tariffs in the hemisphere had not been directed at the United States. Angered by the Argentinian's attempt to deny the forcefulness of his Havana attack, Kellogg lectured Pueyrredón on the US tariff position. He admonished Pueyrredón that United States duties were no more prohibitive than other such barriers in the hemisphere. There was a greater percentage of goods coming into the United States free of duty from Latin America than vice versa. 
Pueyrredón apparently concurred without argument. His passive acceptance of Kellogg's argument only weeks after the inflammatory conference comments evoked a testy response from the Secretary of State. Kellogg recorded that as the Argentine Ambassador 'opened up the subject, I made up my mind that I could not afford to have him think that I did not resent his attitude'. While the Secretary sat fuming, Pueyrredón persisted in discussing his own political prospects. $^{43}$

Having enraged Kellogg, Pueyrredón continued to alienate Foreign Minister Gallardo and other Argentine leaders. In early April, while in Rio de Janeiro, he announced that the ideas he propounded at Havana would succeed 'some day'. Pueyrredón complained that his fellow delegates and the Foreign Ministry had undermined his position at the conference. As such, they had made the nation vulnerable in a time of emergency. Pueyrredón falsely accused the government of conspiring with US delegates against his own position. At Montevideo, he denied having made the Rio de Janeiro comments and thanked United States government officials for their 'open-mindedness' towards his position. He intimated that high-ranking US leaders had admired the courage of his stand, if not the content of his message. Pueyrredón claimed to be on good terms with the United States government. He reported that former president William Howard Taft had 'applauded' his attitude. Pueyrredón's persistent dishonesty contributed to continued US doubts about the Argentine government position. Bliss was never fully convinced that Alvear had not supported, at least in part, his Havana delegation chief. ${ }^{44}$

In the months following the Havana Conference, the United States sought to establish precisely what Pueyrredón had said in Cuba on the subject of antiintervention. The State Department wished to ensure that he would not be able to mask his commentary at a future date. As late as August 1928, Francis White was pursuing Pueyrredón's precise words on anti-intervention. Having finally ascertained this information to his satisfaction, White commented to former US delegate to Santiago and Havana, Henry P. Fletcher, that "[s]hould Pueyrredón bring up this question any more, I think we can put him very definitely in his place once and for all'. Before, during, and after the Sixth Pan American Conference, the United States authorities succeeded in exercising a domineering diplomatic control over the threat to US military and economic interests in Central America. Furthermore, by coordinating that control with widespread Latin American support for a determined US agenda of trade and finance objectives, the United States succeeded in crafting a new, though shortlived Pan American order in which the Pan American Union functioned to defuse controversial political debate and to further United States economic interests. $^{45}$ 


\section{IV - Perspectives on the Argentine Challenge}

The anti-intervention challenge reflected earlier examples of Argentine diplomatic leadership, most notably, Hipólito Yrigoyen's 1917 attempt to rally a Latin American bloc of neutrals that would challenge US wartime leadership. At Havana, the Argentine Foreign Ministry intended to reassert Argentine diplomatic leadership in Latin America. When, on 13 January, Antonio Sagarna cabled instructions that Pueyrredón express Argentine concerns over intervention, the revised Argentine conference position was released to the press. This information was meant for international as well as domestic consumption. On 22 January, the Argentine ambassador to Chile, Manuel Malbrán, informed Sagarna that the news had produced a strong impression in political circles and among diplomatic colleagues in Santiago: 'la cancillería argentina ha exteriorizado una vez más las tradiciones de nuestra política internacional de respeto a la libre determinación e independencia de los pueblos americanos. $^{46}$

Yet, the public Argentine grievance on tariffs was anomalous in a context of extensive cooperation between Argentina and the United States, in matters of Pan American economic policy, through the 1910s and 1920s. The fusion of the two issues by Pueyrredón culminated in a confrontation that was unprecedented in the history of Argentine-United States relations. Furthermore, despite the fact that anti-intervention became an accepted precept at the Seventh Pan American Conference in 1933, no evidence ties Argentina's conference role in that year with Pueyrredón's anti-intervention motion (revoked by the Argentine government after Pueyrredón's resignation) in $1928 .^{47}$

In equating Pueyrredón's stand with that of the 'Argentine government', various authors (most recently, Luis Alén Lascano and Richard V. Salisbury) have argued that Argentine-United States economic conflicts before 1928, over high US tariffs and United States sanitary restrictions against Argentine beef imports, conditioned the 'Argentine' challenge at Havana. The longterm and close cooperation of Argentine officials (both within the Pan American Union structure and in other venues) with US economic objectives belies this contention. ${ }^{48}$ In addition, no documentary evidence supports the assertion that economic motivations guided either government policy or Pueyrredón's personal actions. On the contrary, several factors suggest that there was no political consensus for action on these questions, either inside or outside the Alvear administration. Even though Argentine authorities had criticised high United States tariff barriers since the early 1920s, and continued to petition the United States for reduction on the rates for corn, linseed, and other products, the British Ambassador in Buenos Aires, Sir Malcolm Robertson, understood that Pueyrredón's statement on tariffs was 'strangely shortsighted', in light of Argentina's trade barriers, which were high by international standards. Pueyrredón's position on tariffs seemed 'shortsighted' as economic policy, but not as a personal political tactic that capitalised on a popular anti-imperial mood in Buenos Aires. ${ }^{49}$ 
In late 1926 and 1927, with the promulgation of the United States Department of Agriculture's Bureau of Animal Industry Order (BAI) 298, banning the importation of chilled and frozen cattle from Argentina, the Argentine Rural Society led a vigorous attack against Washington in Congress, in the press, and in other circles. Propounding the slogan 'Buy from those who buy from us', the Rural Society accused the United States of dishonestly implementing a trade barrier in the guise of a sanitary ban (against Foot-and-mouth disease). At first, the Argentine government reacted favourably to the Rural Society accusations and defended the high quality of Argentine cattle. By the time of the Havana Conference, however, and subsequently, a number of important public voices in Argentina began to question the position of the Rural Society and insisted that no retaliatory action against the United States was warranted. These included the national Pork Raisers' Association and many provincial and local rural societies which felt embittered that their interests had not been represented by the national Rural Society, which was intent on concealing the extent of Foot-and-mouth disease in the country. By early 1929, under pressure from the Argentine Industrial Union (representing manufacturers) and other groups, the Rural Society relented in its antagonism towards the United States. Despite the fact that Pueyrredón, as a member of an important landowning family, had strong personal ties to the Rural Society, neither he nor any of the Argentine delegation members reached Havana with the intent to retaliate against BAI Order $298 .^{50}$

The attack on United States policy at the Sixth Pan American Conference did not represent the first public occasion on which the delegation chief had staged a bold and iconoclastic diplomatic incident. In December 1920, as the leader of Argentina's first delegation to the League of Nations, Pueyrredón walked out of that body's meetings when the United States refused Argentina's petition for full League membership for all nations. Yet, while in 1920 Pueyrredón expressed the political will of President Hipólito Yrigoyen, eight years later he took his stand alone. Pueyrredón's independence of action in 1928 accents an important difference between the diplomacy of the United States and that of Argentina. During the first years of the twentieth century, in response to congressional pressures and the growing importance of trade and political contacts abroad, the United States Department of State initiated a programme to depoliticise and professionalise the nation's diplomatic corps. By 1928, the insubordination inherent in Pueyrredón's conduct was foreign to the United States diplomatic corps. Furthermore, Pueyrredón's maverick delivery was in keeping with a long history of Argentine political power and policy-making authority residing in the London and Washington ambassadorships, a context for which there was no equivalent in the United States. Rómulo S. Naón, Ambassador to the United States in the 1910s, and Tomás Le Bretón, Ambassador to Great Britain in the 1940s, were among several to demonstrate that Argentine mission heads in these capitals often initiated policy, beyond specific directives. ${ }^{51}$ 
These factors delineate a backdrop to Pueyrredón's principal motivation in committing Argentina to anti-intervention and an attack on high tariffs. His conference tacks represented a personal political agenda designed to alienate the Alvear administration and to create an opportunity for his reentry into the cabinet of a new Yrigoyen-led regime. Angel Gallardo, former Ambassador to the United States Tomás Le Bretón, and President Alvear, were among many Argentinians who suspected at the time that Pueyrredón's motivation in defying his government had nothing to do with his antipathy to US imperialism, but rather to a careful calculation that former President Yrigoyen would be returned to presidential office later that year. In early 1928, despite the fact that Yrigoyen had not declared his candidacy for the general elections scheduled for April (and would not do so until a week before the vote), many Argentinians began to anticipate that the former president would win a strong majority. Yrigoyen, true to his popular designation, 'el peludo' (the armadillo), made no speeches, no utterances of policy, and no statements of intent until the final stage of the campaign, when he let it be known, in a much-publicised letter to a good will organisation, that if elected president he would donate his salary to charity. ${ }^{52}$

Compelling evidence of a coming Yrigoyen victory surfaced during the Havana conference; gubernatorial elections in the provinces of Tucumán and Entre Ríos convinced many sceptics of el peludo's impending return to office. Reports of these elections, wrote Sir Malcolm Robertson, 'have given such an overwhelming majority to the candidates of the Irigoyenist party' that the opposition forces 'are in a state of complete despair'. 'These two elections', the British Ambassador went on, 'are so strongly indicative of the way that the political wind is blowing that I cannot now find anyone who has the smallest hope of Irigoyen being defeated in April'. Pueyrredón was one of those who understood the implications of the Tucumán and Entre Ríos elections. He anticipated correctly that Yrigoyen would win the presidential election of 1928. Having served in Yrigoyen's cabinet during the 1910s, Pueyrredón hoped to return to a high post in the new government, and said as much to Sir Esme Howard, the British Ambassador to the United States. ${ }^{53}$

While, on his brief sojourn to Washington after the Havana meeting, Pueyrredón tried to assuage angry State Department administrators, he approached the British embassy with a different analysis of Argentina's foreign relations. The United States, Pueyrredón complained, was beginning to look on South America too much as a private preserve. It was almost certain, Pueyrredón continued, that Yrigoyen - a 'friend' of British interests - would be elected President at the coming elections and in this event he, Pueyrredón, would 'probably be appointed Minister of Foreign Affairs'. Speaking already in his expected cabinet-level capacity, Pueyrredón said that he intended to promote economic relations with Great Britain and with other European states to offset 'United States penetration'. ${ }^{4}$ 
At Havana, Pueyrredón found an opportunity to demonstrate his loyalty to Yrigoyen. By combining the Foreign Ministry's ambiguous directives on intervention with his own stand on tariffs, Pueyrredón identified the means of demonstrating adherence to Yrigoyen's political venture. Unlike Alvear, whose popular image was that of a weak president, ${ }^{55}$ Yrigoyen expressed a vociferously anti-interventionist and anti-imperial political message in 1928. By assuming an anti-US posture, Pueyrredón hoped to demonstrate a worldview similar to that of Yrigoyen. Perhaps more important, Pueyrredón probably expected that his coup against the Alvear administration would indicate to Yrigoyen that Pueyrredón exercised power within the Argentine polity, and was therefore a valuable political ally. Furthermore, in challenging Alvear, Yrigoyen's long-term political adversary, Pueyrredón hoped to indicate his allegiance to the former President, while publicly breaking ties with the current chief executive. $^{56}$

More surprising than the delayed response of Espil to Pueyrredón's betrayal of his mandate was the failure of the Foreign Ministry to react to the delegation chief until after Espil's warning telegram of 10 February. As late as 8 February, Gallardo suggested to Sir Malcolm Robertson that he was 'rather proud' of the Argentine delegation chief. It is possible that Gallardo's own political allegiances were mixed; in the February political tumult that followed the Yrigoyenist political victories in provincial elections, the Buenos Aires weekly Caras y Caretas intimated that the Foreign Minister might back Yrigoyen in the coming contest. Moreover, in the lead-up to the conference and at the time Pueyrredón made his inflammatory remarks, Gallardo was preoccupied with a long visit to Europe, which began in December and from which he did not return until after the conference began. Editors of the Review of the River Plate could not explain what affairs of state Gallardo intended to conduct in Europe. The 'original, ostensible' motive of the tour had been to assist at the unveiling of a monument to General Belgrano at Genoa. But beyond this, and while the crucial final instructions to Havana conference delegates had been left in the hands of Antonio Sagarna, Gallardo's chief European objective seemed ceremonial. His itinerary highlighted an audience with the King of Italy, a luncheon at Buckingham Palace, and meetings with various heads of state. ${ }^{57}$

That the Havana Conference took place during the traditional Argentine summer vacation probably contributed to the lethargy of the Argentine government reaction. Through January 1928, the press sharply criticised Alvear for spending too much time at the summer resort of Mar del Plata and too little time attending to the affairs of state. It would have been inconceivable for the United States Department of State to have delegated the issuance of final conference instructions to one of Kellogg's subordinates; at the Argentine Foreign Ministry, Acting Secretary Antonio Sagarna sent out final instructions to Pueyrredón while both Gallardo and Alvear remained away from Buenos Aires. It seems certain that neither Alvear nor Gallardo suspected Pueyrredón's duplicitous intent. There was no Argentine precedent for so 
openly rebellious a stand on the part of a diplomat, and until Espil's telegram, Gallardo and Alvear gave no indication that they mistrusted Pueyrredón. When Alvear finally realised the extent of Pueyrredón's defiance, he reacted bitterly: 'What do you think of this ambassador!' the President declared angrily to Gallardo. Pueyrredón was trying to 'find a pretext to resign, in order to ingratiate himself with Irigoyen'. Alvear countered angrily that he would not 'give him the pleasure', explaining, in part, the government's initial reluctance to accept Pueyrredón's resignation. ${ }^{58}$

The political cynicism that drove Pueyrredón's Havana challenge is revealed in his friendly attitude towards the United States in the year prior to the conference. Only months before the meeting, the Ambassador had taken a long automobile trip through the United States. He had published his very favourable impressions of the United States in several newspapers, lauding such diverse elements of American society as grain elevators, national parks, highways, and workers' living standards. In a tone vastly different from his interjections at the Havana Conference, Pueyrredón had written,

In looking into the life of this country one appreciates the intelligent energy with which it is gifted and the spirit of renovation in all its progress, shown by a constant productive action which incorporates methods and means of ever increasing advancement and employs its capital in every useful enterprise which promises any possibility of success. $^{59}$

At Havana, Pueyrredón did not prove a consistent opponent of the United States on all issues relating to US imperialism, further underlining the careful and political nature of his choice of antagonistic topics. More to the point, when he took the side of the United States, he can be said to have represented firmly the position of the Alvear government. In the reprise of a matter studied in 1923, at the Fifth Conference of American States in Santiago de Chile, the Mexican delegation entered a motion that the offices of Chairman and DirectorGeneral of the Pan American Union, currently held by US citisens, should be rotated annually and alphabetically among the twenty-one member nations. Also, the Mexicans asked that Latin American countries send 'special' delegations to the Pan American Union intimating that the current representatives, the diplomats assigned to the United States, were under US influence. Hughes argued against the motion. He noted that the Pan American Union Constitution did not prohibit member states from sending whomever they wished to represent their interests, and that the office of chairman, consistently occupied by a representative of the United States, was no more than a post of honour. Hughes was backed successfully by Honorio Pueyrredón who led a number of Latin American delegates in supporting the continued chairmanship of the body by the United States. ${ }^{60}$

In a related instance, and in specific reference to US military interventions in the Caribbean basin, the Mexicans asked the conference to adopt a motion 
by which, when a revolutionary group seized the port of an established government, member nations would cease to trade through the occupied harbour. Mexico received its only support, for parochial reasons, from El Salvador and Nicaragua. Pueyrredón, representing his government in no uncertain terms, led a successful rejection of the proposal. During 1927, in even stronger contrast to his anti-intervention stance at Havana, Pueyrredón demonstrated sympathy for the mounting turmoil faced by the US government in Nicaragua. Throughout the 1920s, Argentina had expressed sympathy for Central American nations under US domination, but had never taken a firm stand against United States military intervention. In late 1926, the Argentine minister in San José, Costa Rica, Atilio Daniel Barilari, supplied the Foreign Ministry with damning and explicit details of the US military intervention in Nicaragua. But in 1927, when Nicaraguan rebel leader Juan B. Sacasa approached Barilari for Argentine support in mediating the Nicaraguan crisis, Barilari refused. While offering Sacasa assurances of his assistance, Barilari counselled Angel Gallardo against an Argentine mediation role; despite the blatant injustice of US intervention, Barilari advised, the Argentine government had nothing to gain in leading a diplomatic challenge against the United States. Barilari noted that with Sacasa's rebels only 90 miles from Managua, an important battle was imminent. With uncertain prospects for Nicaragua's political future, Argentine leaders would be wise to avoid backing one side or the other. Gallardo concurred. Argentina offered Sacasa nothing more than moral support. ${ }^{61}$

Yet, also in 1927, a year before his Havana challenge to US authority, Pueyrredón offered to mediate the Nicaraguan controversy in his capacity of Argentine Ambassador in Washington, and in a manner conducive to United States interests.

Pueyrredón understood the need for ambiguity in mediation, on the part of the the United States, and was pointedly vague in his approach. He offered Kellogg an Argentine mediation that could be entirely non-binding, and applied at the discretion of the Department of State. His country's mediators would act neither as judges nor as arbitrators. They would take 'friendly action' to arrive at a satisfactory solution - precisely the ill-defined terms the United States might consider as a basis for negotiation. Kellogg politely refused the offer, with the qualification that if the need arose, he would certainly call on the Argentines. Yet, the Secretary of State did accept the overture as 'proof' of Argentine friendship and the laudable Argentine determination to maintain good relations among the nations of the Americas. The Argentine Ambassador had won a small diplomatic triumph; 'I can assure your Excellency', Pueyrredón wrote to Gallardo, 'that this message [the proposal to Kellogg] has produced an excellent impression'. Only weeks later, Sacasa met personally with Barilari in Costa Rica. Barilari's counsel to the Foreign Ministry remained the same: Argentina would gain maximum advantage by allowing the conflict in Nicaragua to run its course, before declaring in favour of one faction or another. $^{62}$ 
In his 10 February telegram to Gallardo and Alvear, Felipe Espil revealed to his government what Pueyrredón's Nicaragua-related contact with Kellogg also indicated - the calculating politics inherent to Pueyrredón's actions. But after the conference, Espil made even more far-reaching criticisms of the Pan American structure. Pan Americanism, Espil wrote, had no 'natural base' to justify its existence. In a familiar Argentine refrain, Espil believed that the Argentine affinity for Europe took precedence over any allegiances Argentina owed other Latin American states. The geographical delimitation for membership in the Pan American Union was deceiving. Argentina was much closer to Europe or to the United States than to Caracas or Bogotá in terms of travel time, extent of trade, and the European composition of the Argentine population. Espil cited one of Argentina's first leaders, Bernardino Rivadavia, as the authority for his statements. For similar reasons, according to Espil, Rivadavia had refused to participate in the first inter-American conference, organised by Simón Bolívar. ${ }^{63}$

Espil's disillusionment went further than his distaste for identifying Argentina with its less developed Latin American neighbours. The diplomat had supported staunchly the US objective of commercial normalisation. His contempt for Pueyrredón's attacks on the United States had been based, in part, on a concern that the delegation chief was upsetting the commercially-oriented Pan American structure. Now, less than a month after the Havana Conference, Espil expressed his displeasure with the ambiguities of the Pan American movement. He was sceptical of much the delegates had achieved, and he criticised the document Pueyrredón had refused to sign for the reorganisation of the Pan American Union:

It is curious to note, that it did not occur to anybody to question what motives of necessity, urgency or convenience, made it preferable to exchange the [former] convenient, in a sense informal system.... for the more formal and less elastic system which now results in a Convention. ${ }^{64}$

Espil was troubled at his own complicity in the ambiguity of the Pan American Union's projects. The new regulations were conceived more formally than those they replaced. But there was little functional difference. Espil complained that, for the small changes accepted, the conference might have addressed the issue under less auspicious circumstances than as a main article of conference discussion. The Counsellor deplored that more energy had not been spent resolving precise economic problems.

Espil grasped the inefficacy of economic progress in Pan Americanism. A staunch supporter of US goals of trade and financial normalisation, he identified the Pan American Union's inability to address specific Latin American problems, but seemed not to gather that the United States had no interest in pursuing these concerns. Washington supported generalised regulations facilitating international trade. But were the Pan American Union to consider the detailed problems of particular nations, the organisation might 
be transformed into a medium through which member states could press the United States on its trade policy, an unacceptable scenario for US planners.

Surprisingly, after precipitating his superior's ouster from office, Espil criticised Pueyrredón for the weakness of the preamble the latter had fought to include in the Pan American document. After Havana, Espil told the Foreign Ministry that Pueyrredón's preamble had not gone far enough in calling for a significant economic reorganisation. In the half-heartedness of its attack on United States tariffs (and as a function of Pueyrredón's political motivations), it had conformed to, rather than confronted, the limited scope of Pan American trade and finance projects. The proposed insertion was impractical and could only have had a symbolic impact. Espil wanted problems of Latin American development to be confronted on a point-by-point basis at conferences with strict economic orientations.

On the delegates' decision to postpone a consideration of military intervention, Espil again reflected his country's non-confrontational approach to US hegemony. He understood that the codification of international law had been discussed at Havana without the practical criteria needed to effect a solution to the problem. The diplomat had no doubt that even if Maúrtua's opponents had realised a formal codification of the rules of international conduct, the Pan American Union could offer no practical medium for their implementation. Espil could suggest no alternative course of action for that which had been taken. It must not have escaped the delegates' attention, Espil noted, that the Monroe Doctrine was the basis for United States military interventions. This cornerstone of US policy was a unilateral declaration, on whose interpretation 'the United States had declared themselves the only judges' and to which the question of non-intervention would be 'intimately related'. Although one of the most prominent participants in the United States-dominated Pan American order, consolidated in 1928, Espil seemed not fully appreciative of the manner in which the United States had structured the Union.

\section{V - Conclusion: Consolidating Control}

Espil's ingenuous remarks on United States control within the Pan American Union, and his articulation of US economic interests within the Pan American order, represent both the ascendancy of the United States within the interAmerican body and the accompanying growth of US commercial and financial activities in Argentina and elsewhere in South America. ${ }^{65}$ Havana marked the beginning of a short-lived crest in United States influence within the Pan American Union, representative of US economic strength - and interrupted by the Great Depression. At the Sixth Conference, both the United States and Argentine governments followed agendas in keeping with those their diplomats had articulated at earlier Pan American meetings. Increasingly, after the First Meeting of the American States in 1889, US officials had come to view the Pan American Union as a forum through which avenues of commercial and 
financial opportunity could be opened, in association with expanding United States economic interests in Latin America. ${ }^{66}$ From a rigorous pursuit of Latin American trade opportunities in 1910, at the Fourth Conference in Buenos Aires, US officials acted after 1915 to control financial and investment policies in the hemisphere through agreements at Pan American financial meetings. ${ }^{67}$

In 1923, at the Fifth Conference of American States (the Santiago Conference), the United States began to coordinate two features of its Pan American policy that would emerge as crucial to the defeat of anti-interventionism at the Havana Conference five years later - the centrality of economic objectives and the importance of diplomatic control. On the eve of the Santiago meeting, Secretary of State Charles Evans Hughes enjoined US delegates to stress problems of commercial and financial normalisation. ${ }^{68}$ To achieve the unhindered implementation of the US conference agenda, ${ }^{69}$ Hughes inaugurated undemocratic controlling tactics, that would be applied successfully in 1928, and again at future gatherings (including the wartime First and Second Meetings of hemispheric Foreign Ministers in 1939 and 1940, and at the 1954 Caracas Conference). Hughes insisted that conference discussion not vary from an immutable conference agenda, and remain free of controversial topics. ${ }^{70}$ Though to an extent more limited than US tactics before Havana, Hughes engineered a diplomatic offensive to secure Latin American support for Washington's conference objectives. In addition, he voiced a concern that would trouble both him and Secretary of State Frank B. Kellogg five years later at the Havana Conference: United States authorities did not wish criticisms of American expansionism to be aired at the conference. ${ }^{71}$

Unlike US officials, Argentine government delegates reached the Santiago and Havana Conferences without the tradition of a determined Pan American policy, cogent economic objectives for the hemisphere, or clear conference goals. At the 1910 Buenos Aires Conference, the Argentine government admitted that the United States had led in the preparation and execution of the conference agenda. As Washington dominated Pan American financial meetings after 1915, Argentine authorities failed to articulate a distinct financial policy, apart from the goal of securing private US bank loans. ${ }^{72}$ While US diplomacy at Santiago centred on restricting discussion to trade- and financerelated themes, the Argentine government approached the Fifth Conference without an independent, substantive plan to place before the delegates. Faced with failed postwar prospects for beef markets in Europe, a mounting foreign debt, and the restrictions of the Fordney-McCumber Tariff in the United States, Argentine leaders hoped that economic development lay in stronger commercial and financial ties with the United States and other industrialised countries. The Argentines accepted the United States Pan American model for economic development, stressing commercial normalisation and financial stability. Where the Argentine government planned to introduce variants in the predetermined agenda, delegates were instructed not to question US objectives, but merely to propose adjustments in details. Argentina explicitly supported most US projects at the meeting. ${ }^{73}$ 
This support, at Santiago and Havana, reflects rising economic ties between Argentina and the United States during the 1920s. Between 1910 and 1928, as Washington's primacy defined a new Pan American order, the expansion of United States trade and financial interests in Argentina paralleled equivalent US expansion elsewhere in South America. Many Argentine leaders believed that their nation's prosperity would be tied to the continued growth of bilateral trade links with the United States. During the first three decades of the century, to be sure, British economic influence in Argentina remained stronger than that of the United States. But the percentage of direct US overseas investment in Argentina - and in South America generally - increased steadily. The 1920s witnessed the first notable flow of US capital investment into Argentina. By 1924 , US investment in Argentine industry reached almost $\$ 100$ million. In 1928 and 1929 alone, the International Telephone and Telegraph Corporation and the American and Foreign Power Company sent nearly $\$ 160$ million to Argentina. And by 1930 , direct US investment in Argentina, some $\$ 335$ million, was third in Latin America to the amounts invested in Cuba and Mexico. $^{74}$

Whereas in 1913 Argentina's share of United States direct investment in Latin America was only 3\%, by 1929 this figure had risen to $11 \%$. Brazil experienced a similar increase, from $4 \%$ to $9 \%$, and in Chile, the equivalent statistics are $1 \%$ to $7 \%$. For 1929, the value of Argentine exports to the United States represented twice that for 1921 and four times that for 1913. More significantly, the nature of US economic penetration abroad became more multi-faceted. Portfolio investment (by which investors financed the operation of a firm without assuming a controlling interest) changed the manner in which US policy-makers viewed economic opportunity in the Southern Cone, as did new legislation in the 1910s that opened new foreign opportunities for United States banks. ${ }^{75}$

As the First World War approached, Argentina was selling increasingly to the British (the traditionally dominant foreign power in the River Plate region) and buying progressively more from the United States. The war set a telling precedent for the decline in British influence: Argentina made its first largescale loans to England so that the British could continue to buy agricultural produce. Great Britain's heightening balance-of-trade deficit with Argentina was reinforced after the war as a rapid escalation in private US loans to the Argentine government replaced earlier British financing. In the meat-packing industry, Argentina's most vital sector, United States companies made tremendous inroads. Almost immediately after 1907-1909, when Swift \& Company of Chicago and other US houses acquired Argentine packing plants, these American firms began to assert dominance over the industry. By 1910, American packing house output in Argentina claimed a major share of the British market, at the expense of beef packed by British and Argentine houses. At the outbreak of the First World War, American companies controlled $41.35 \%$ of beef exports. The British maintained a $40.15 \%$ share while 
Argentine houses were left with only $18.5 \%$. US houses maintained a high percentage of beef exports through the $1920 \mathrm{~s}^{76}$

In 1925, the United States became the principal supplier of foreign goods to Argentina, surpassing the once predominant British and by the time of the Havana gathering, the International Harvester Company and other United States firms supplied more than $95 \%$ of Argentina's agricultural machinery. Packards, Fords, and other North American vehicles prevailed on Argentina's burgeoning road network and many feared that this sector of United States exports might compete directly with British-owned railroads. By 1929, Argentina had eclipsed Cuba as the best customer for United States goods in Latin America. While the State Department conceived of the Pan American Union as an avenue for improved economic relations with Latin America generally, many Argentine leaders understood their nation's economic interests to be tied to US objectives for trade and financial normalisation, through agreements and codifications of the Pan American Union. In short, for different though related trade interests, Argentina and the United States arrived at Havana with similar economic objectives. ${ }^{77}$

United States control at the Havana Conference and the defeat of the Argentine challenge marked the successful conclusion of a campaign for economic and diplomatic primacy in Latin America. Even so, Pueyrredón's contradictory remarks in the aftermath of his resignation reinforced Kellogg's erroneous conviction that foreign powers were manipulating Argentine anti-US positions. Never clear on the extent to which Pueyrredón's views on tariffs and intervention were an expression of his government's policies, Kellogg continued to believe that Pueyrredón's position on Central America emanated from 'Moscow', and was 'aided and abetted by Mexico and also by Communistic organisations' in the United States. ${ }^{78}$ This projection of a Red Menace onto Argentina ignored a lingering bitterness in the Buenos Aires Foreign Office towards the government in Moscow, primed initially by the mistreatment of Argentine Counsellor J. Naveillán in the aftermath of the Russian Revolution. Through the Alvear administration, as grounds for maintaining no formal relations with the Soviet Union, Gallardo cited that country's interference in the internal affairs of other nations - precisely the criticisms Kellogg levelled against the Soviets. ${ }^{79}$

Although Ambassador Bliss could provide only weak supporting evidence, Kellogg became persuaded that anti-US hostility in Argentina was also the work of European commercial rivals. He believed that European newspapers had 'tried in every way to stir up trouble' at Havana. The Secretary noted bitterly that British, French, and Italian journalists had joined in the attack on US interventionism while their governments had relied on the US military to protect European trading interests. The European press, it turned out, was more vehement in its assault on US military intervention in Central America than was the Argentine government. ${ }^{80}$ 
Pueyrredón gambled his political future on a break with his own history of pro-US diplomacy. In combining the Argentine Foreign Ministry's ambiguous instructions on Nicaragua with a harsh attack on high US tariffs, Pueyrredón wrongly assumed that the anti-US credentials he had earned at Havana would assure him a high-ranking post in the new Yrigoyen administration. By consolidating the support of the many Latin American governments, won months before the gathering, the United States was able to disarm the antiintervention threat. President Alvear and Foreign Minister Gallardo falsely presumed that Honorio Pueyrredón would comply with his professional duties as a diplomatic representative. In the first weeks of 1928, the Argentine government determined that the seemingly unqualified support it had promised to Ambassador Bliss represented too vigorous a backing of United States foreign policy - a position that might damage its international credibility with other Latin American states, should an anti-intervention resolution gain force. Yet by no means were the last-minute instructions to Pueyrredón issued as a challenge to the United States. Argentine leaders wished to pursue a foreign policy tack that suggested solidarity with other Latin American countries, while maintaining sound economic relations with the United States. Pueyrredón took advantage of this precarious balance. He not only countered his government's interests, but also broke with the spirit of his own recent Nicaraguan mediation offer to Secretary Kellogg. The Argentine Foreign Ministry could not control the damage Pueyrredón caused. Because of this, the United States remained suspicious of the Argentines long after the conference ended.

After the Havana Conference, the State Department savoured its victory. Francis White and others began a covert diplomatic probe into Pueyrredón's precise words while Frank Kellogg planned quickly for a follow-up Pan American meeting to reaffirm the triumph over Guerrero and Pueyrredón. Within weeks of the US delegates' departure from Havana, the Secretary of State approached Charles Evans Hughes with a new mission. This time the venue would be Washington. A Conference on Conciliation and Arbitration was called by Pan American Union members to comply with their Havana resolution to discuss these matters at a later date. ${ }^{81}$ The conference would represent a capstone to the US diplomacy of control at Havana. In the establishment of elaborate rules for the mediation and arbitration of international differences, the United States could avoid any scrutiny of its own military adventurism in Latin America. ${ }^{82}$

President Calvin Coolidge first hesitated to ask Hughes to return to public service. The President worried that the State Department was riding 'a willing horse to death'. Hughes accepted Kellogg's invitation. His condition was that the American government follow the Havana example in establishing strict diplomatic control and a careful grip on the conference agenda. Hughes asked for preliminary meetings with members of the Senate and an exchange of views with Latin American governments. He reasoned that the United States should not enter a conference of such importance "with the chance of disruption on 
account of extreme demands or of an endeavor to put the United States in an unfortunate position before the public opinion of the world' ${ }^{83}$

The Alvear administration accepted the United States invitation to the arbitration and conciliation conference, naming as the country's delegates Carlos A. Alcorta and Luis A. Podesta Costa, technical advisers in the Argentine delegation at Havana. For reasons that are not clear, the Yrigoyen administration did not send the delegation. ${ }^{84}$ US authorities organised the conference with the endorsement of many of the same states that had supported Hughes at Havana. And after recent Senate recommendations in favour of an arbitration accord with Mexico, Coolidge believed himself to be in an unprecedented position of strength to negotiate a compulsory Pan American arbitration treaty. ${ }^{85}$ A diverse variety of arbitration treaties between the United States and different Latin American republics existed at the time of the Sixth Pan American Conference. The US government intended to unify and standardise these agreements, in the hope of concentrating further Pan American authority in Washington; by delimiting a formal grievance procedure for international disputes, United States policy-makers believed they could defuse the more public criticisms of US intervention witnessed at Havana. Policy-makers did not expect the results of the Washington Conference to obstruct United States military and political objectives in Central America.

Standing arbitration treaties with Brazil, Ecuador, Haiti, Peru, and Uruguay called for the submission of disputes to the Permanent Court of Arbitration at the Hague. US officials planned to eliminate the differences in these accords. The United States hoped to implement an earlier treaty proposed at the Santiago Conference, and ratified by only some member countries. The 1923 Treaty to Avoid or Prevent Conflicts between the American States differed substantially from agreements the United States had reached earlier with Latin American states. $^{86}$ An important provision of the 1923 Treaty was the formation of a Permanent Committee on Arbitration with its seat at Washington. With the implementation of this accord, the United States would achieve the transference of international arbitrating authority from Europe to the United States. ${ }^{87}$

The conference was held between 10 December 1928 and 5 January 1929, only nine months after Pueyrredón's contentious statements. Coolidge inaugurated the gathering and delegates elected the Secretary of State conference president. Kellogg maintained strict control of proceedings; in addition to the usual powers of a conference chair (to preside over meetings and submit topics for discussion), Kellogg had the authority to prescribe all measures necessary for the 'maintenance of order' and the strict compliance with meeting regulations. ${ }^{88}$ Conferees hastily modified international commissions of conciliation created by the 1923 Convention, one of several notable changes enacted; until the Washington Conference of 1928-1929, only nations directly threatened by war could call such commissions into action. Now, any Pan American Union member could nominate the commissions to act, imparting a multinational basis for arbitration. ${ }^{89}$ 
The Washington Conference aimed to provide a structured medium for the elimination of conflict in the Americas. As such, delegates empowered (indeed compelled) arbitration tribunals to reach swift verdicts within three months of their convening. Such rulings would be binding. On 5 January 1929, all Pan American Union member states (with the exception of the absent Argentina) signed a General Treaty of Inter-American Arbitration. Yet the treaty would prove as limited in ending international conflict as was the League of Nations. The Mexican Foreign Ministry prematurely reported that during the conference the subject of armed conflict between Paraguay and Bolivia had arisen: 'The Conference offered its good offices and the conflict was avoided.' The conference could actually provide no practical structure for alleviating escalating Bolivian-Paraguayan hostilities that would lead to the Chaco War. ${ }^{90}$

For the United States the meeting represented a successful ending to the problem of anti-intervention. The Havana Conference had provided a forum for criticism of American foreign relations, no matter how proficiently those criticisms had been countered. The Conference on Conciliation and Arbitration subsumed the question of military intervention under a Pan American forum even more carefully dominated by the United States. The well-intentioned delegates in Washington obscured the combative interference of Honorio Pueyrredón and others by promulgating a set of regulations that could not be implemented practically. In organising the conference and carefully overseeing its outcome, the United States had protected itself, for the time being, from further challenges against military intervention within the Pan American Union.

The period of US diplomatic control within the Pan American Union was brief, but coincided with unprecedented United States economic achievements in Argentina and in the hemisphere. Consul General George S. Messersmith described the late $1920 \mathrm{~s}$ as a golden era for US interests in Argentina: ${ }^{91}$

Those were flourishing days in the Argentine. We had very important interests established in the country. American firms, such as Swift \& Armour and Wilson, were very important in the meat-packing business. American interests had started the cement industry in the Argentine. Our people were increasingly active in the industrialization in the Argentine taking place at that time. ${ }^{92}$

In 1929, American investors bought millions of dollars worth of British shares in South American concerns. Also in the year of the stock market crash and the onset of worldwide depression, the specialisation and quality of US exports secured certain markets for which goods from other nations could not compete. George Jackson Eder, head of the Latin American Section of the Bureau of Foreign and Domestic Commerce, estimated that fully $75 \%$ of United States exports to Argentine markets could not be challenged effectively because of production advantages. In reference to the Havana Conference, the British Foreign Office clerk G.H. Thompson commented that it was possible to attach too much importance to the 'anti-United States sentiments of Latin-Americans'. 
Their lack of solidarity and the powerful economic position of the United States vis-à-vis Central and South America made these sentiments 'rather futile'. 'However unpopular Wall Street might be', Thompson wrote, 'it also has its uses. 93

Five years after the Havana Conference, at the height of the Great Depression, delegates met for the Seventh Pan American Conference in Montevideo. Influenced in part by the 1932 outbreak of war between Bolivia and Paraguay in the Chaco, the Argentine Foreign Minister Carlos Saavedra Lamas reached Uruguay promoting an Anti-War Pact. More strictly founded in international precedents than Pueyrredón's challenge, and supported by several Latin American delegations, the Argentine proposal incorporated elements of earlier arbitration and conciliation accords, including the Kellogg-Briand Pact of 1928. The Anti-War Pact explicitly prohibited foreign interventions. However, the anticipated US-Latin American clash over the scheme never occurred. Since 1929, the strategic and economic position of the United States had changed markedly in relation to Argentina and within the Pan American movement generally. At the Seventh Pan American Conference in Montevideo, articulating Roosevelt's Good Neighbor Policy, Secretary of State Cordelly Hull announced a position that reversed Charles Evans Hughes's defence of intervention. Hull told his fellow delegates that the United States would no longer entertain military intervention as a foreign policy option. ${ }^{94}$

Latin American diplomats and politicians - Argentine Foreign Minister Saavedra Lamas among them - congratulated themselves on having evoked so significant a reversal in United States-Latin American relations. Without question, Latin American pressures played an important role in Hull's concession to the national sovereignty of Latin American states. At Havana, the United States became party to a Convention on Rights and Duties of States, the eighth article of which stated that "no state has a right to intervene in the internal or external affairs of another'. The US economic retreat, however, was the overriding factor in the American diplomatic reversal. Before 1933, harsh economic conditions in the United States, compounded by international retaliation to the Smoot-Hawley Tariff, led to a decline in US strategic and commercial power in Latin America, and to the collapse of the dominance of the Pan American Union by the United States in the late 1920s. That strength would not be recaptured by Washington until the Second World War, after which the United States quickly set about renewing predominance within the newly constituted Organization of American States. 


\section{Notes and References}

The author acknowledges the financial support of the Social Sciences and Humanities Research Council of Canada, and is grateful to Mr. John A. Purcell, and to Professors Thomas G. Paterson, Stephen J. Randall, Roger Gravil, Mark T. Gilderhus, Peter Blanchard, and Richard V. Salisbury for their helpful comments on drafts of this work.

1. 'Statement by Dr. Honorio Pueyrredón', Translation, 12727, Foreign Office File 371 (FO 371), Public Record Office (cited hereafter as PRO); Robert T. Pell, 'Washington Diplomats at Havana', Special Supplement on the Occasion of the Sixth Pan-American Conference (Washington, DC: Capital City News Association, 1928); No. 296, Pueyrredón to Minister of Foreign Relations, 4 February 1928, Expediente 5, VI Conferencia Internacional Americana, División Política (Pol), Archivo del Ministerio de Relaciones Exteriores y Culto (cited hereafter as MRE); Harold F. Peterson, Argentina and the United States, 1810-1960 (Albany, NY: State University of New York, 1964), p. 376; Luis C. Alén Lascano, Pueyrredón: El mensajero de un destino (Buenos Aires: Editorial Raigal, 1951), pp. 118-134; Luis Alén Lascano, Yrigoyen, Sandino y el panamericanismo (Buenos Aires: Centro del Editor, 1986), pp. 116-119; No. 3871, 'Argentina (Political)', 27 February 1928, 2657-L-72, Military Intelligence Division (MID), Record Group (RG) 165, National Archives of the United States (cited hereafter as NA); Robert E. Olds, Under Secretary of State, to United States Embassy, Buenos Aires, 9 February 1928, 710.F002/236a, RG 59, NA.

2. Frank B. Kellogg, United States Secretary of State, to the United States Delegation in Havana, 19 February 1928, 710.F/346b, RG 59, NA. See also, 'La Conférence Panaméricaine s'est terminée hier sur l'équivoque,' Le Matin (Paris), 21 February 1928; 'Le nouvel empire', L'Information (Paris), 21 February 1928; 'O Brasil e os Estados Unidos na conferência de Havana', $O$ Jornal (Rio de Janeiro), 25 February 1928.

3. The Department of State also identified the Mexican and Salvadoran delegations (and, in particular, the Salvadoran Gustavo Guerrero) as working against the interests of the United States. But heightened US concerns about Pueyrredón were based on the erroneous conception that Argentina had significant influence among its Latin American neighbours, and intended to use the anti-intervention issue at Havana as a starting point for an Argentina-led organisation that would challenge the role of the United States-dominated Pan American Union. See Francis White, Assistant Secretary of State, to Robert Woods Bliss, United States Ambassador to Argentina, 29 February 1928, Francis White Papers, Herbert Hoover Presidential Library (cited hereafter as HHPL). On the role of Gustavo Guerrero at the Havana Conference, see Richard V. 
Salisbury, Anti-Imperialism and International Competition in Central America, 1920-1929 (Wilmington, DE: Scholarly Resources, 1989).

4. The literature that considers the clash over intervention at the 1928 Havana Conference comprises memoirs, monographs on the bilateral relations of the United States and several countries, more general studies of inter-American relations, and other genres. A small sample of the important works addressing the Sixth Conference includes Samuel Flagg Bemis, The Latin American Policy of the United States: An Historical Interpretation (New York: 1943); Lester D. Langley, America and the Americas: The United States in the Western Hemisphere (Athens, GA: The University of Georgia Press, 1989); J. Lloyd Mecham, The United States and Inter-American Security, 1889-1960 (Austin, TX: University of Texas Press, 1961); Frederic Jessup Stimson, My United States (New York: Charles Scribner's Sons, 1931); Fredrick B. Pike, Chile and the United States, 1880-1962 (Notre Dame, IN: University of Notre Dame Press, 1963); Gordon Connell-Smith, The United States and Latin America: An Historical Analysis of Inter-American Relations (London: Heinemann Educational Books, 1974); Peterson, Argentina; Enrique Gil, Evolución del panamericanismo (Buenos Aires: Librería y Casa Editora de Jesús Menéndez, 1933); Salisbury, Anti-Imperialism; Joseph S. Tulchin, Argentina and the United States: A Conflicted Relationship (Boston, MA: Twayne Publishers, 1990). Luis C. Alén Lascano's Pueyrredón: El mensajero de un destino and Yrigoyen. Sandino y el panamericanismo embody a theme in the Argentine historical literature celebrating Pueyrredón as a defender of the rights of selfdetermination. Stephen J. Randall's The Diplomacy of Modernization represents an important revision of the significance of the meeting; it charts a ColombianUnited States commercial conflict in the context of a long-term bilateral dispute. In the successful resolution of the conflict, from the point of view of the United States government, Randall illustrates a case of controlling diplomacy similar to that considered in this study.

5. Walter LaFeber, Inevitable Revolutions: The United States in Central America (New York: W. W. Norton \& Company, 1983), pp. 64-66; Neill Macaulay, The Sandino Affair (Durham, NC: Duke University Press, 1985 [orig. 1967]), pp. 24-25; Frank Niess, A Hemisphere to Itself: A History of US-Latin American Relations (London: Zed Books Ltd., 1990 [orig. 1984]), pp. 86-87.

6. Walter Lippman, 'Vested Rights and Nationalism in Latin-America', Foreign Affairs 5 (April 1927), pp. 353-363. See also George Black, The Good Neighbor: How the United States Wrote the History of Central America and the Caribbean (New York: Pantheon Books, 1988); Ronald Steel, Walter Lippman and the American Century (Boston, MA: Little, Brown and Company, 1980), pp. 237-238. The harshest press criticisms of Kellogg's Central America policy 
appeared in The New Republic. See, for example, 'Nicaragua Occupied', The New Republic, 5 January 1927; 'The Week', The New Republic, 19 January 1927.

7. Congressional Record, 69 cong, 2d sess, January 1927, pp. 1428-1429, 1445, 1883; L. Ethan Ellis, Frank B. Kellogg and American Foreign Relations (New Brunswick, NJ: Rutgers University Press, 1961), pp. 70-71; 'Two Years of Mr. Kellogg', The New Republic, 26 January 1927. See also Douglas Little, 'Antibolshevism and American Foreign Policy, 1919-1939: The Diplomacy of Self-Delusion', American Quarterly 35 (Fall 1983), pp. 376-390.

8. The career diplomat William Castle wrote in February 1928 that 'the Secretary ought to get away. His temper is bad and he lives in a state of continual grouch. He cannot decide things'. See Entry 13, February 1928, William Castle Diary, HHPL.

9. Kellogg to Delegates of the United States of America to the Sixth International Conference of American States, Havana, Cuba, 5 January 1928, Box 16, Entry 145, RG 43; Philander L. Cable, United States Chargé d'Affaires in Buenos Aires, to Secretary of State, 7 January 1927, 817.00/4413, RG 59, NA. See also, No. 312, George L. Kreeck, United States Minister to Paraguay, to Secretary of State, 3 May 1927; No. 357, Kreeck to Secretary of State, 27 July 1927, 810.43-Anti-Imperialistic League/15, RG 59, NA.

10. Arthur C. Frost, United States Consul General, Tampico, Mexico, to Secretary of State, 18 April 1927; 'Radical Activities of the International AntiImperialistic League of America', undated report from a confidential US source in Tampico, Mexico, 810.43-Anti-Imperialistic League/9, RG 59, NA. See also 'El Partido Socialista de la Argentina se niega a ser instrumento del imperialismo Yanqui', El Libertador (Mexico City) 2 (August 1927), p. 7; 'La Argentina se verá envuelta en una guerra', Boletín de la Liga Anti-Imperialista (Buenos Aires) 2 (May 1926); Manuel Caballero, Latin America and the Comintern (Cambridge: Cambridge University Press, 1986). In 1929, the United States Office of Naval Intelligence reported that the Anti-Imperialist League was financing directly Sandino's military campaign (Serial No. 141, 28 May 1929, 14000L, C-10-I, Office of Naval Intelligence (ONI), RG 38, NA).

11. No. 142, Bliss to Secretary of State, 817.00/5350; No. 333-G, Cable to Secretary of State, 29 June 1927, 835.00/399, RG 59, NA.

12. Alvear and Gallardo to President of the Senate, 29 July 1927, Memoria 1927 (Buenos Aires: Ministry of Foreign Relations, 1928), pp. 32-33; 'Los sucesos de Nicaragua', La Nación, 4 January 1928; 'La política intervencionista de los 
Estados Unidos es hoy la piedra de toque del panamericanismo', La Nación, 5 January 1928; No. 135, Bliss to Secretary of State, 10 January 1928, 817.00/5349, RG 59, NA; Aníbal Pablo Jaúregui, 'Comercio y no intervención: dos temas conflictivos en las relaciones argentino-norteamericanas, 1922-1928' (Unpublished paper, 1986).

13. Francis White to United States Diplomatic Mission Chiefs in Latin American Countries, 4 August 1927, 710.F/30a; Hughes to Secretary of State, 4 February 1928, 710.F1b Public International Law/11, RG 59, NA.

14. Kellogg to Bliss, 7 November 1927, Reel 29, Frank B. Kellogg Papers, Manuscript Division, Library of Congress, Washington, DC (cited hereafter as LC), (originals in Minnesota Historical Society).

15. Francis White to Chiefs of the Diplomatic Missions in Latin American Countries, 4 August 1927, 710.F/30a, RG 59, NA.

16. No. 498, Grant-Smith to Secretary of State, 22 October 1927, 710.F002/62; Grant-Smith to Secretary of State, 10 December 1927, 710.F002/100, RG 59, NA.

17. Miles Poindexter, United States Ambassador to Peru, to Secretary of State, 26 December 1927, 710.F002/144; No. 472, Summerlin to Secretary of State, 10 November 1927, 710.F/153; No. 477, Summerlin to Secretary of State, 22 November 1927, 710.F002/95; No. 1711, Arthur H. Geissler, United States Minister to Guatemala to Secretary of State, 22 November 1927, 710.F002/78; No. 1451, Jesse S. Cottrell, United States Minister to Bolivia, to Secretary of State, undated, 710.002/170; Jefferson Caffery, United States Minister to El Salvador to Secretary of State, 17 January 1928, 710.F002/210; No. 699, Evan E. Young, United States Minister to the Dominican Republic, to Secretary of State, 15 November 1927, 710.F002/53; No. 1171, Samuel H. Piles, United States Minister to Colombia, to Secretary of State, 17 October 1927, 710.F1a/1 10; No. 1101, Richard M. de Lambert, United States Minister to Costa Rica, to Secretary of State, 13 December 1927, 710.F1a/175; No. 1234, Myron A. Hofer to Secretary of State, 12 November 1927, 710.F/161, RG 59, NA; 'Conference Policy. Relations with the United States, Relations with Other Countries, Of the States, other than the United States, attending the Sixth International Conference of American States at Habana in January, 1928', Box 22, Entry 148, RG 43, NA.

18. 'Memorandum of conversations between the President of Cuba and the Chief of the Division of Latin American Affairs on the train from Key West, Florida, to Washington, April 22, 1927', 25 April 1927, 837.00/2655, RG 59, NA. 
19. No. 61, Bliss to Secretary of State, 3 November 1927, 710.F002/59, RG 59, NA. The State Department seems to have ignored a December 1927 report from an unnamed agent of the Office of Naval Intelligence who insisted that Argentina would ask for a consideration of the armed intervention of the United States in Nicaragua and would call for a motion 'against any intromission of a country in the internal or external affairs of another' (Report of L-34, Serial No. 671, 15 December 1927, 14000k, C-10-1, ONI, RG 38). Bliss would later express his 'chagrin' for having reported to the State Department that the 'appointment of Ambassador Pueyrredón augured well for a favorable understanding between the American and Argentine delegations'. The British ambassador, Sir Malcolm Robertson, however, had failed also to predict that Argentina would play a leading role in conference deliberations. In addition, Bliss did not report that Felipe Espil had contradicted the United States at an international gathering in the recent past. In 1927, at the Inter-American Air Aviation conference, Espil had opposed the United States' contention that certain areas open to commercial planes of national registration should be closed to foreign aircraft. The United States cited Panama as an example. Espil had maintained that planes from all countries should receive equal treatment in any area where commercial flying was permitted. At the International Radio Telegraphic Conference that same year, Espil had been a staunch supporter of a US project for the reorganisation of radio traffic in the hemisphere. He had, 'on several occasions presented motions which the [North] American delegates had found difficulty in raising before the committees'. Pell, 'Washington Diplomats at Havana'; No. 36, Robertson to Sir Austen Chamberlain, Secretary of State for Foreign Affairs, 8 February 1928, 12727, FO 371, PRO.

20. 'Ha llegado de Lima el nuevo ministro ante el gobierno de Cuba', $L a$ Nación, 15 November 1927; No. 72, Bliss to Secretary of State, 17 November 1927, 710.F002/87, RG 59, NA.

21. 'Address of Hon. Henry P. Fletcher, at the Dinner of Council on Foreign Relations, March 8, 1928', White Papers, HHPL; Sheldon Whitehouse, United States Delegate to the Sixth Pan American Conference, to Secretary of State, 16 January 1928, 710.F/235 Section III, RG 59, NA; Major Charles Todd Richardson, United States Military Attaché in Argentina, 'Current Events for the Month of January', 31 January 1928, 2048-182:24, MID, RG 165, NA. For a consideration of one of many other topics dealt with at Havana, see K. Lynn Stoner, 'In Four Languages, but with One Voice: Division and Solidarity of Pan American Feminism, 1923-1935', Paper presented at the meeting of the Latin American Studies Association, Arlington, Virginia, April 1991. 
22. No. 2, Antonio Sagarna, Acting Foreign Minister, to President of the Argentine Delegation to the Sixth Pan American Conference, 13 January 1928, Expediente 5, VI Conferencia Internacional Americana, Pol, MRE.

23. On 20 January, an editorial in the Review of the River Plate stated that 'a considerable body of Argentine public opinion appears to regard the intervention of the United States in Nicaragua as an international misdemeanour, at least, and the Press of Buenos Aires, with a unanimity its diversified components seldom achieve, claims to reflect that opinion. There is a strong feeling that the question of Nicaragua should be raised at the Conference, notwithstanding that the Argentine agenda presents no visible opening for the introduction of the subject' ('Notes on News', Review' of the River Plate, 20 January 1928). See also, 'La cuestión de Nicaragua es contemplada por el poder ejecutivo', La Argentina (Buenos Aires), 13 January 1928; 'No satisface la Declaración del Poder Ejecutivo Nacional', Crítica (Buenos Aires), 13 January 1928; 'Esta es la Ocasión', La Razón, 13 January 1928; 'La Argentina y la situación de Nicaragua', La Acción, 13 January 1928; 'La Conferencia Panamericana', La Nación, 16 January 1928; 'La Sexta Conferencia Panamericana', La Prensa, 16 January 1928; Jorge A. Mitre', 'El Recuerdo de Nicaragua', La Nación, 17 January 1928; 'El discurso de La Habana', La Razón, 17 January 1928; No. 6, Sagarna to Argentine Legation, Havana, 18 January 1928, Expediente 5, VI Conferencia Internacional Americana, Pol, MRE.

24. No. 4, Pueyrredón to Minister of Foreign Relations, 26 January 1928, Expediente 5, VI Conferencia Internacional Americana, Pol, MRE.

25. The Spanish term ponente (or in more recent usage, deponente) is translated as deponent. This usage is suggestive of the authority this committee leader held; the ponente presented and, more important, made preliminary interpretations of topics for discussion. As such he established the terms and set the tone of debate.

26. Maúrtua's interpretation of international law included a statement that 'every nation has the right to exist, and to protect and conserve its existence; but this right neither implies the right nor justifies the act of the State to protect itself or to conserve its existence by the commission of unlawful acts against innocent or unoffending States.' This concession to the traditional US motive for intervention - the violation of property rights and the rights of individuals - was complemented by specific reference to the United States Constitution and Bill of Rights: 'Every state is independent in the sense that it has the right to the pursuit of happiness and to develop itself freely without intervention and control of other states, but in the exercise of this right it must not interfere with or violate the rights of other States'. See 'Address of Hon. Henry P. Fletcher, at 
the Dinner of Council on Foreign Relations, March 8, 1928', White Papers, HHPL; No. 66, Espil to Gallardo, 30 March 1928, 'Informes Sobre Desarrollo de sus deliberaciones y actuación de los delegados Argentinos', Expediente 12, VI Conferencia Internacional Americana, Pol, MRE.

27. Gil, Evolución del panamericanismo, p. 113; No. 66, Espil to Minister of Foreign Relations, 30 March 1928, VI Conferencia Internacional Americana, Pol, MRE.

28. Refer to Section IV for further reference to the sanitary question. See, 'Address of Hon. Henry P. Fletcher, at the Dinner of Council on Foreign Relations, March 8, 1928'; 'The Outlook for Pan Americanism - Some Observations on the Sixth International Conference of American States', Address of Charles E. Hughes, at the Hotel New Willard, Washington, 26 April 1928, White Papers, HHPL.

29. Ibid. Several Latin American countries engaged in significant tariff increases in the late 1920s and early 1930s, including Cuba, Guatemala, Peru, Chile, and, in 1931, Argentina. See Chester Lloyd Jones, Clerk, Department of State, to Charles Evans Hughes, 10 January 1927, White Papers, HHPL; Department of Commerce, Bureau of Foreign and Domestic Commerce, 'Memorandum - Latin American Countries', 16 May 1931; Department of Commerce, Bureau of Foreign and Domestic Commerce, 'Latin American Countries', 16 May 1931, Hoover Papers, Presidential, HHPL; 'Notes on News', Review' of the River Plate, 5 August 1927; A. O'Connell, 'Free Trade in One (Primary Producing) Country: The Case of Argentina in the 1920s', in Guido di Tella and D.C.M. Platt, eds., The Political Economy of Argentina, 1880-1946 (London: St. Antony's College/The MacMillan Press, 1986).

30. Why Espil, a staunch ally of United States objectives for normalised hemispheric trade, waited more than two weeks to denounce Pueyrredón's spectacular deviation from Argentine government economic policy remains unclear. Evidence suggests that the diplomat was troubled deeply by his decision to confront his superior. According to his wife, Courtney Letts de Espil, after informing on Pueyrredón, Espil was uncharacteristically despondent throughout the day. That evening, the normally staid and efficient diplomat drank champagne to excess and wandered the streets of Havana through the night, bemoaning his fate. When he reached his bed at daybreak, Espil was convinced that his career was ruined. These actions suggest two potential contributing factors to the delay. First, Espil understood that whatever the outcome of his complaint, Pueyrredón would remain a powerful political force in Argentina and, therefore, a threat to the younger diplomat's career. Second, as an experienced professional in the Argentine diplomatic corps, Espil was 
probably uncomfortable with turning on a superior, especially one with whom he had served in the same post for several years; when called to Havana, Pueyrredón was Ambassador to the United States, while Espil was the Washington embassy's Counsellor. See Courtney Letts de Espil Diary, Book II, 295, LC; Espil to Gallardo, 18 May 1928, Expediente 12, VI Conferencia Internacional Americana, Pol, MRE.

31. No. 3871, 'Argentina (Political)', 27 February 1928, 2657-L-72, MID, RG 165, NA; No. 184, Bliss to Secretary of State, 15 February 1928, 710.F002/280; .MDNM/No. 238, Bliss to Secretary of State, 2 April 1928, 710.F002/303, RG 59, NA; 'Espil y Pueyrredón', Crítica (Buenos Aires), 25 February 1928; Bliss to Secretary of State, 10 February 1928, 710.F002/238, RG 59, NA.

32. 'Texto de los telegramas cambiados', La Nación, 18 February 1928.

33. Bliss to Secretary of State, 13 February 1928, 710.F002/245, RG 59, NA. On interventions and the threat of interventions in Buenos Aires province during the 1910s and 1920s, see Richard J. Walter, The Province of Buenos Aires and Argentine Politics, 1912-1943 (Cambridge: Cambridge University Press, 1985). Without understanding that Pueyrredón's criticism of high tariffs conflicted with the Argentine government position, the State Department remained puzzled at Pueyrredón's refusal to sign the reorganisation document (a position for which he received the support of no other delegation). Assistant Secretary of State Francis White simply assumed that Pueyrredón's stubbornness outweighed common sense: 'when all of Pueyrredón's arguments had been answered', White wrote, 'and shown to be unsound and untenable and he had no further answer to make, he simply said, pig-headedly, that he would not sign. The result was that even Guerrero was disgusted with him and the Brazilians, Chileans, Peruvians, and all others, were outspoken in their indignation'. See White to Bliss, 29 February 1928, White Papers, HHPL.

34. No. 18, Gallardo to Pueyrredón, 15 February 1928, Gallardo to Pueyrredón, VI Conferencia Internacional Americana, Pol, MRE.

35. Major C. T. Richardson, United States Military Attaché in Argentina, 'Current Events for the Month of January', 31 January 1928, 2048-182:24, MID, RG 165, NA; 'The Incident at Havana', Buenos Aires Herald, 17 February 1928; 'Los secretos de la ineficaz cancillería argentina', La Prensa, 17 February 1928.

36. No. 15, Olascoaga to Gallardo, 16 February 1928; No. 20, Gallardo to Olascoaga, 17 February 1928, Expediente 5, VI Conferencia Internacional Americana, Pol, MRE. 
37. 'List of Motions, Agreements, Resolutions, and Conventions adopted at the Sixth International Conference of American States, and statement of action to be taken in each case', unpublished Memorandum; 'Address of Hon. Henry P. Fletcher, at the Dinner of Council on Foreign Relations, March 8, 1928'. Francis White Papers, HHPL; Department of State, Division of Latin-American Affairs, 'Review of Questions of Major Interest in the Relations of the United States with the Latin American Countries, 1929-1933', Herbert Hoover Papers, Presidential, HHPL.

38. It seems clear that Olascoaga did not mean his criticism to undermine the decision already taken by conference delegates to postpone discussion of antiintervention. In Buenos Aires, the press mocked his 'kilometric discourse that said nothing', incomprehensible to those who heard it. See 'Un discurso lamentable', La Prensa, 22 February 1928.

39. David J. Danelski and Joseph S. Tulchin, eds., The Autobiographical Notes of Charles Evans Hughes (Cambridge, MA: Harvard University Press, 1973), pp. 275-278. Francis White understood the distinction between hostility towards US interests and the domestic political needs some delegates felt to indicate their regret, once the subject of intervention had been reopened. 'Nearly all had to get up for home consumption', White reasoned, 'and talk against intervention when it was publicly mentioned... which is understandable...' (See White to Bliss, 29 February 1910, White Papers, HHPL). The Guatemalan government, in deference to the United States, never released the text of Tello's statement to the press (No.36, 17 March 1928, Gerald Harrington, British Consul to El Salvador, to Chamberlain, 12727, FO 371, PRO).

40. Charles Evans Hughes, Our Relations to the Nations of the Western Hemisphere (Princeton, NJ: Princeton University Press, 1928), pp. 13-20; Danelski and Tulchin, Autobiographical Notes, pp. 275-278.

41. José Joaquín Caicedo Castilla, El panamericanismo (Buenos Aires: Roque Depalma editor, 1961), pp. 44-46; Minutes, Third Session, Jan. 30, 1928, Committee No. 6, Report on Trade Marks, Box 12, Entry 128, RG 43, NA. On 20 February 1929, largely as a result of Espil's initiative, Pan American member states (with the exception of Argentina) signed a new trade mark agreement. See 'Convention and Protocol Between the United States and Other American Republics Respecting Trade Mark and Commercial Protection and Registration of Trade Marks, signed February 20, 1929', Foreign Relations of the United States (henceforward FRUS), vol. 1, 1929 (Washington: Government Printing Office, 1943), pp. 670-692. 
42. 'Recommendations Proposed by the Delegation of the United States of America for the Consideration of the Sixth Committee on Economic Problems of the Sixth International Conference of American States Relative to Topic 4: Revision of the Conventions Signed at Buenos Aires in 1910 and at Santiago, Chile, in 1923, with a view to formulating changes which will assure uniform and effective protection for trade marks in the States members of the Pan American Union', undated, 710.F002/2, RG 59, NA; White to Henry L. Stimson, Secretary of State, 13 May 1931, White Papers, HHPL.

43. Francis White to Bliss, 21 March 1928, 701.3511/309; Kellogg to United States Embassy, Buenos Aires, 22 March 1928, 701.3511/310; Memorandum of Conversation with Honorio Pueyrredón, 1 March 1928, 710.F002/264, RG 59, NA.

44. Continued State Department suspicions were fuelled by a second Argentine challenge to United States foreign policy. On 28 February, the Argentine diplomat José Cantilo criticised the Monroe Doctrine before the League of Nations. He implied that in future the doctrine's legitimacy would depend on broad approval in Latin America, not merely on a unilateral United States declaration. As had Pueyrredón's statements a month before, Cantilo's comments received tremendous press dissemination in Europe and South America. This latest attack on the United States was 'received with malicious pleasure', wrote Bliss, 'on the part of certain of [Cantilo's] Latin American colleagues in Geneva and... enjoyed a succés fou in the Latin American bloc in Paris'. Like Pueyrredón, almost certainly Cantilo made his inflammatory remarks independent of Foreign Ministry instructions. Bliss to Secretary of State, 1 March 1928, 710.11/1166; No. 554, S. Pinkney Tuck, United States Consul in Geneva, to Secretary of State, 6 March 1928, 500.a15c/67; No. 250, Bliss to Secretary of State, 16 April 1928, 710.F002/308, RG 59, NA; 'La doctrina de Monroe', La Nación, 1 March 1928.

45. Part of the difficulty in ascertaining Pueyrredón's exact words, in the midst of his elaborate denials, was that many important discussions had taken place in committee and sub-committee meetings where no verbatim records had been kept. See White to Bliss, 22 March 1928; Hughes to Kellogg, 14 May 1928, White Papers, HHPL; Bliss, Memorandum on 'Conversation with the Argentine Ambassador', 1 March 1928, 710.F002/264, RG 59, NA; White to Fletcher, 17 May 1928; White to Fletcher, 25 August 1928, Container 14, Henry P. Fletcher Papers, LC; White to Hughes, 12 May 1928; Hughes to White, 14 May 1928; White to Hughes, 17 May 1928; No. 595, Gerhardt Gade, United States Chargé d'Affaires in Uruguay, to Secretary of State, 13 April 1928; No. 253, Bliss to Secretary of State, 18 April 1928, Reel 5, Papers of Charles Evans Hughes, LC. 
46. In contrast to the positive appraisals Malbrán received from diplomatic colleagues and many Chileans, the government-controlled El Mercurio reported the Argentine position on intervention without comment - ostensibly because Chile intended to support the United States on all issues. 'Comunicado Oficioso de La Cancillería Argentina', El Mercurio (Santiago), 13 January 1928; No. 5, Malbrán to Sagarna, 22 January 1928, Expediente 5, VI Conferencia Internacional Americana, Pol, MRE.

47. Francis White believed that one of Pueyrredón's objectives was 'to crystallize anti-American feeling around Argentina which would become the champion and leader of the so-called weak States of this hemisphere against the hegemony of the United States'. See White to Bliss, 29 February 1928; White to Bliss, 3 March 1928, Francis White Papers, HHPL. See also, Lottie M. Manross, United States Policy Toward Argentina: A Survey of Past and Present Policy, Public Affairs Bulletin, 49 (Washington, DC: Library of Congress Legislative Service, 1947); Peterson, Argentina.

48. The successful negotiation of a new loan between the Argentine government and a group of New York bankers, as the anti-intervention conflict unfolded at Havana, was the clearest sign that bilateral trade and financial relations were not affected by the Havana Conference. On 3 February 1928, Alvear signed a decree accepting the offer of long term loans of \$20 Million. The issue was negotiated in New York by the Chase Securities Corporation and Messrs. Blair and Company. See 'Argentina's Latest Loan', Review' of the River Plate, 10 February 1928.

49. No.36, 8 February 1928, Robertson to Chamberlain, 12727, FO 371, PRO; Conversation, Secretary of State with Manuel E. Malbrán, Ambassador of Argentina, 4 October 1928, 'Investigation by Tariff Commission into Cost of Production of Corn and Linseed in Argentina and Adhesion by Argentina to Multilateral Treaty', White Papers, HHPL. The 6 December 1923 Argentine Tariff Law, still in force in 1928, had represented an augmentation in tariff values by more than $60 \%$ over figures specified in the earlier legislation passed in 1906. In 1926, Argentina earned \$122 Million and in 1927, \$129 Million from tariff duty revenue ('Argentine Foreign Trade in 1927', Review' of the River Plate, 27 January 1928).

50. This view challenges a recent interpretation by Joseph S. Tulchin who writes that Pueyrredón 'vented his spleen' at Havana over his association of the beef ban with US tariff prohibitions on Argentine agricultural produce (see Tulchin, Argentina and the United States, pp. 49). Commerce between the United States and Argentina seemed not to suffer from the political controversy over the sanitary ban. During the first ten months of 1927 , trade between the two nations 
amounted to some $\$ 850$ million, an increase of $26 \%$ over the equivalent period the year before. During August and September, at the height of Argentine animosity over BAI Order 298, the Review of the River Plate reported a 'spectacular increase' in exports from Argentina to the United States. See, 'Trade Between Argentina and the United States', Review of the River Plate, 2 December 1927; Juan E. Richelet, The Argentine Meat Trade (Paris: Société Industrielle D'Imprimerie, 1929); Manuel A. Machado, Jr., Aftosa: A Historical Survey of Foot-and-Mouth Disease and Inter-American Relations (Albany, NY: State University of New York Press, 1969); Arturo O'Connell, 'La fiebre aftosa, el embargo sanitario norteamericano contra las importaciones de carne y el triángulo Argentina-Gran Bretaña-Estados Unidos en le periodo entre las dos guerras mundiales', Desarrollo Económico 26 (April-June 1986), pp. 21-50; ‘A Plea for Common Sense', The Buenos Aires Herald, 1 February 1929; No. 102, George S. Messersmith, United States Consul-General in Argentina, to Secretary of State, 5 February 1929, 611.353/13; No. 492, J.C. White, United States Chargé d'Affaires in Argentina, to Secretary of State, 7 March 1929, 611.353/16, RG 59, NA; 'La defensa de la producción nacional', La Nación, 2 February 1929; 'La Sociedad Rural Argentina insiste y amplía sus anteriores conceptos sobre la política económica del país', La Prensa, 28 February 1929.

51. Joseph S. Tulchin, 'The Origins of Misunderstanding: United StatesArgentine Relations, 1900-1940', in Guido Di Tella and D. Cameron Watt, eds., Argentina Between the Great Powers, 1939-1946 (Oxford: MacMillan/St. Antony's, 1989), p. 45; A.F. Orchard, Staff Officer, 'Dr. Hipolito Irigoyen', 11 April 1928, 12376, FO 371, PRO; No. 2495, 'The International Policy of President Yrigoyen', 18 October 1921, 2657-L-24, MID, RG 165. No. 2765, 'Political Estimate of Argentina', 15 May 1922, 2657-L-50, MID, RG 165; Gabriel del Mazo, La primera presidencia de Yrigoyen (Buenos Aires: Centro Editor de América Latina, 1983), pp. 171-183; Roberto Etchepareborda, Yrigoyen/l (Buenos Aires: Centro Editor de América Latina, 1982), pp. 155-159. On the reorganisation of the United States diplomacy, see Huntington Wilson, 'The American Foreign Service', The Outlook, vol. 82 (3 March 1906), pp. 499-504; Waldo H. Heinrichs, Jr., American Ambassador: Joseph C. Grew and the Development of the United States Diplomatic Tradition (New York: Oxford University Press, 1986 [orig. 1966]); Richard H. Werking, The Master Architects: Building the United States Foreign Service, 1890-1913 (Lexington, KY: University of Kentucky Press, 1977).

52. On 31 January 1928, Sir Malcolm Robertson wrote to the Head of the Foreign Office American and African Department that 'there seems very little doubt but that Irigoyen or a puppet of his, will be returned. The man is amazing. He never appears, has made no speech and sued no manifesto...'. (Robertson to R.G. Vansittart, 31 Jan 1928, 12376, FO 371, PRO). See also: 
David Rock, Politics in Argentina: The Rise and Fall of Radicalism, 1890-1930 (Cambridge: Cambridge University Press, 1975); Federico M. Moreno Quintana, La Diplomacia de Yrigoyen (La Plata: Editorial Inca, 1928); Roberto Etchepareborda, Yrigoyen/2 (Buenos Aires: Centro Editor de América Latina, 1983); Gabriel del Mazo and Roberto Etchepareborda, La segunda presidencia de Yrigoyen (Buenos Aires: Centro Editor de América Latina, 1984).

53. No. 37, 11 February 1928, Robertson to Chamberlain, 12736, FO 371, PRO. In spite of his efforts, Pueyrredón did enter the cabinet during Yrigoyen's last years as President. Nicholas L. Biddle attaches similar importance to the Salta gubernatorial election (Biddle, 'Oil and the Right in the 1928 Election', Paper presented at the meeting of the Latin American Studies Association, Arlington, Virginia, April 1991). See also Luis C. Alén Lascano, Yrigoyenismo y antipersonalismo (Buenos Aires: Centro Editor de América Latina, 1986).

54. No.501, Howard to Chamberlain, 6 March 1928, 12727, FO 371, PRO.

55. Alvear's confrontations with the Yrigoyenista Congress led to failure on most important Executive legislative initiatives. The President's attempt to reaffirm Argentine participation in the League of Nations represented one such defeat. After six years of trying to gain congressional approval for the initiative, Gallardo confided to the British First Secretary in Buenos Aires, V.A.L. Mallet, that 'we must admit that we have failed completely'. A6116, No.180, Mallet to Lord Cushendun, Acting Secretary of State for Foreign Affairs, 8 Aug. 1928, 12738, FO 371, PRO.

56. The US operatives were not alone in their confusion over Pueyrredón's motivations and the extent to which he contradicted Alvear's authority. The British Ambassador in Buenos Aires never grasped Pueyrredón's determination to contradict his superiors for political gain. And the Chilean Ambassador to Argentina felt slighted when Pueyrredón announced in opposition to intervention; in the belief that the Peruvian delegation would curry favour with the United States, in return for support in the Tacna-Arica question, and with the expectation that Brazil would back the United States, the Chilean government felt isolated on the eve of the conference. As a result, the Chilean government had approached Argentina with a proposal for a joint motion on antiintervention. The Argentine Foreign Ministry had refused the suggestion, so that when Pueyrredón made his statement, the Chileans resented what seemed like deceitful behaviour on the part of the Argentinians. See No. 36, Robertson to Chamberlain, 8 February 1928, 12727, FO 371, PRO. 
57. No.36, 8 February 1928, Robertson to Chamberlain, 12727, FO 371, PRO; No. 25 Gallardo to Pueyrredón, 6 February 1928, Expediente 5, VI Conferencia Internacional Americana, Pol, MRE; 'Notes on News', Review of the River Plate, 23 December 1927; No. 2352A, Ray Atherton, US Chargé d'Affaires in London, to Kellogg, 20 December 1927, 033.3540/2, RG 59. A satirical poem in Caras y Caretas mocked the Foreign Minister for his European visit which was replete with pomp and ceremony, but devoid of significant political or economic accomplishments:

¿A qué fue al Viejo Mundo?

-No lo sabe

-¿Y a qué ha vuelto?

-Lo ignora'

Luís García, 'Volvió', Caras y Caretas, 11 February 1928. See also 'Regreso del Canciller Argentino de su jira por Europa', Caras y Caretas, 4 February 1928.

58. No. 196, Bliss to Secretary of State, 2 March 1928, 710.F002/291, RG 59, NA; Angel Gallardo, Memoria para mis hijos y nietos (Buenos Aires: Academia Nacional de Historia, 1982), p. 495.

59. No. 95, Bliss to Secretary of State, 6 December 1927, 701.3511/296, RG 59, NA. Pueyrredón also shared US prejudices against Japanese immigrants and once described Charles Evans Hughes as 'the greatest living man'. See Entry 1 October 1924, Castle Diary, HHPL.

60. No. 479, Howard to Chamberlain, 2 March 1928, 12727, FO 371, PRO.

61. No. 322, Barilari to Gallardo, 21 December 1926; No. 6, Barilari to Gallardo, 8 February 1927; No. 3, Gallardo to Barilari, 9 February 1927, Expediente 1, Legajo 2, Caja 2489, Nicaragua, Pol, MRE; 'Por qué la Argentina Rechazó la Sugestión de Sacasa', El Universal Gráfico (Mexico City), 17 May 1927; 'La Argentina y su política latinoamericanista', Excelsior (Mexico City), 12 March 1927; 'El Brasil y la Argentina cooperan con el imperialismo norteamericano', Excelsior, 1 March 1927.

62. No. 28, Pueyrredón to Gallardo, 22 February 1927; No. 139, Barilari to Gallardo, 7 June 1927, Expediente 1, Legajo 2, Caja 2489, Nicaragua, Pol, MRE. At the time that Pueyrredón approached Kellogg, the United States was in the midst of an escalation of military activities in Nicaragua, through late 1926 and early 1927. When Pueyrredón made his offer, he probably knew that in January 1927, both Sacasa and General Díaz had expressed their interest in a United States-supervised election to settle the Nicaraguan conflict, and that the State Department had made clear its willingness to perform this task. He 
certainly understood the growing domestic political tensions over Nicaragua as powerful politicians, such as Senators George Norris and William Borah, began to come forward in opposition to United States policy in the region. In April 1927, United States President Calvin Coolidge sent his personal envoy, Henry L. Stimson, on a peace mission to Nicaragua. See Lejeune Cummins, Quijote on a Burro: Sandino and the Marines, a Study in the Formulation of Foreign Policy (Mexico: Impresora Azteca, 1958), p. 114; also Ellis, Kellogg, p. 75; Macaulay, Sandino Affair, pp. 28-31. 'Senator George W. Norris Says', Good Neighborship (Bulletin of the National Citizens Committee on Relations with Latin America), August 1927.

63. No. 66, Espil to Minister of Foreign Relations, 30 March 1928, Expediente 12, VI Conferencia Internacional Americana, Pol, MRE.

\section{Ibid.}

65. On US economic influence in Latin America see, among others, Michael L. Krenn, US Policy Toward Economic Nationalism in Latin America, 1917-1929 (Wilmington, DE: Scholarly Resources Books, 1990); Walter LaFeber, The New' Empire: An Interpretation of American Expansion, 1860-1898 (Ithaca, NY: Cornell University Press, 1963); Joan Hoff Wilson, American Business and Foreign Policy, 1920-1933 (Lexington, KY: University of Kentucky Press, 1971); Stephen J. Randall, The Diplomacy of Modernization: ColombianAmerican Relations, 1920-1940 (Toronto: University of Toronto Press, 1977); Joseph Tulchin, The Aftermath of War: World War I and US Policy Toward Latin America (New York: New York University Press, 1971); Emily Rosenberg, Spreading the American Dream: American Economic and Cultural Expansion, 1890-1945 (New York: Hill and Wang, 1982); Charles Evans Hughes, Our Relations to the Nations of the Western Hemisphere (Princeton, NJ: Princeton University Press, 1928).

66. Valerie Fifer, United States Perceptions of Latin America, 1850-1930: A 'New' West' South of Capricorn (Manchester: Manchester University Press, 1991), pp. 153-157.

67. No. 72, Townley to Sir Edward Grey, Secretary of State for External Affairs, 17 August 1910; Foreign Office Memorandum, R.L. Craigie, Clerk of the Commercial and Sanitary Department, Foreign Office, 12 September 1910, 33097, FO 368, PRO; Mark T. Gilderhus, Pan American Visions: Woodrow Wilson in the Western Hemisphere, 1913-1921 (Tucson, AZ: University of Arizona Press, 1986), pp. 60-61; William Jennings Bryan, Secretary of State, to United States Embassy, Buenos Aires, 12 March 1915, 810.51/53; Robert Lansing, State Department Counsellor, to the Diplomatic Officers of the United 
States of America in Latin America, 10 July 1915, 810.51/309b; 'Memorandum', 13 April 1916, 810.51/628; Fredric Jessup Stimson, United States Ambassador to Argentina, to Lansing, 7 April 1916, 710.11/268; McAdoo to President Woodrow Wilson, 28 October 1914, 810.51/585, RG 59, NA; William G. McAdoo, Pan American Financial Conference (Washington, DC: Government Printing Office, 1915); International High Commission, Memorandum on the Topics Submitted by the United States Section of the International High Commission to the Argentine Government, with a Favorable Recommendation for Inclusion in the Program of the First General Meeting of the International High Commission, at Buenos Aires, April 3, 1916 (Washington, DC: Government Printing Office, 1916); Lansing, Secretary of State, to United States Diplomatic Officers in Latin America, and United States Consul in San José, 22 October 1919, 810.51a/73a; Treasury Department, 'The Permanent Committee on Communications', 11 May 1920; David F. Houston, United States Treasury Secretary, to Secretary of State, 22 May 1920, 810.51a/259, RG 59, NA; Robert Neal Seidel, 'Progressive Pan Americanism: Development and United States Policy Toward South America, 1906-1931' (Ph.D. dissertation, Cornell University, 1973), pp. 121-122. Important economic progress at Pan American conferences is summarised in José Joaquín Caicedo Castilla, El Panamericanismo.

68. During the 1920s, US economic policy within the Pan American Union corresponded to equivalent objectives in other international contexts. United States delegates at the Santiago and Havana conferences advocated the unification of tariff nomenclature, the normalisation of customs formalities, and an international campaign against animal and plant disease. In 1927, the United States advocated these same issues at the League of Nations' International Economic Conference. See 'Report of Henry M. Robertson, Member of the Dawes Commission, President of the First National Bank, Los Angeles, Chairman of the United States Delegation to the International Economic Conference in Geneva, to the President of the United States, May 1927', 10 June 1927, Box 31; 'Suggested Attitude and Action by the United States Delegation to the Geneva Economic Conference on the Question of Customs Nomenclature and Classification', undated, submitted by Members of Subcommittee No. 2b, Box 32, Norman H. Davis Papers, LC.

69. Delegates approved a variety of trade rules for the hemisphere encompassing regulations for the uniformity of merchandise nomenclature and guidelines for trade mark protection (which itemised specific measures to ensure compliance, including the establishment of regulatory offices in Havana and Rio de Janeiro). See, Castilla, El panamericanismo, p. 45; 'Convention for the Protection of Commercial, Industrial, and Agricultural Trade Marks and Commercial Names', United States, Department of State, FRUS, vol. 1, 1923, (Washington: 
Government Printing Office, 1938), 297-308; 'Convention Providing for Uniformity of Nomenclature for the Classification of Merchandise', FRUS, vol. 1, 1923, pp. 318-320; 'Memorandum on Customs Nomenclature and Classification', sub-committee 2b, Geneva Economic Conference on the Question of Customs Nomenclature and Classification, May 4, 1927, Davis Papers, LC.

70. Edwin C. Wilson, Division of Latin American Affairs, to Francis White, Acting Chief, Division of Latin American Affairs, 10 October 1922, 710.E1a/15, RG 59, NA. See also 'Observations on the Monroe Doctrine', Address Delivered Before the American Bar Association at Minneapolis, Minnesota, August 30, 1923, reproduced in Charles Evans Hughes, The Pathway of Peace: Representative Addresses Delivered During His Term as Secretary of State (1921-1925) (New York: Harper \& Brothers, Publishers, 1925).

71. Edwin C. Wilson to Francis White, 10 October 1922, 710.E1a/15, RG 59; Serial No.85, file No.103-100, 25 May 1923, 16184, C-10-h, ONI, RG 38, NA; 'El programa de la conferencia de Santiago', La Prensa, 8 November 1922.

72. No. 32, Townley to Grey, 6 June 1910, 23929, FO 371, PRO; 'Opening of Congress', The Standard, 6 May 1910; Alfredo Díaz de Molina, José Figueroa Alcorta: de la oligarquía a la democracia (Buenos Aires: Editorial Plus Ultra, 1979), pp. 349-360; Ricardo C. Aldao to Fredric J. Stimson, 12 May 1915, Frederic Jessup Stimson Papers, Massachusetts Historical Society, Boston, MA; No. 1876, Hacherly to Secretary of State, 30 August 1920, 810.51a/276; No. 1005, Stimson to Secretary of State, 28 November 1919, 810.51a/205, RG 59, NA; 'Argentine Public Opinion: The American Representatives at the Financial Conference', Buenos Aires Herald, 28 January 1920; 'Argentine Public Opinion: Prophets Abroad', Buenos Aires Herald, 1 February 1920.

73. 'Instrucciones: Quinta Conferencia Internacional Americana', Caja 23, V Conferencia Internacional Americana, Pol, MRE; 'Motions for the Program of the Fifth Pan American Conference', 710.E1a/14; W. Henry Robertson, 'Argentine Cattle Crisis', 31 January 1923, 835.6222/19, RG 59, NA; 'Revelaciones de interés sobre la crisis ganadera', La Nación, 23 January 1922, 'The Argentine Cattle Crisis', Review of the River Plate (Buenos Aires), 8 December 1922, 'An Admirable and Aclaratory Action', Buenos Aires Herald, 3 July 1923; 'La mafia de los pseudo-hacendados lleva a la ruina a los ganaderos del país, es necesario que termine la farsa de los falsos apóstoles', La Acción (Buenos Aires), 30 June 1923. On the economy of early 1920s Argentina see Gravil, The Anglo-Argentine Connection, 1900-1939 (Boulder, Colorado: Westview Press, 1985); Guido Di Tella and Manuel Zymelman, Los ciclos económicos argentinos 
(Buenos Aires: Editorial Paídos, 1973); Adolfo Dorfman, Historia de la industria argentina (Buenos Aires: Ediciones Solar, 1970); Peter H. Smith, Politics and Beef in Argentina: Patterns of Conflict and Change (New York: Columbia University Press, 1969).

74. Peterson, Argentina, p. 347.

75. Yanqui Dollar: The Contribution of US Private Investment to Underdevelopment in Latin America (New York: North American Congress on Latin America, 1971).

76. Peter H. Smith, Politics and Beef in Argentina: Patterns of Conflict and Change (New York: Columbia University Press, 1969), pp. 58-60; Simon G. Hanson, Argentine Meat and the British Market (Stanford, CA: Stanford University Press, 1938), p. 163.

77. Roger Gravil, 'Anglo-US Trade Rivalry in Argentina and the D'Abernon Mission of 1929', in David Rock, ed., Argentina in the Twentieth Century (Pittsburgh, PA: University of Pittsburgh Press, 1975).

78. Kellogg to Bliss, 5 March 1928, Reel 31, Kellogg Papers, LC. In a curious coincidence, with no relevance to Kellogg's ideological fixation on Bolshevism, Pueyrredón later represented the Yuzhamtorg trading company (a subsidiary of the Soviet Union's New York-based Amtorg company) in his capacity as a lawyer. On 4 January 1931, on behalf of Yuzhamtorg, Pueyrredón approached the Argentine government with a proposal by which the Soviet company would sell the Argentine government several million dollars worth of gasoline per annum. The Soviets, by the terms of Pueyrredón's offer, would receive payment in hides, wool, bulls, and livestock products. In a still more curious twist, the Argentine cabinet rejected the proposal, believing it would undercut the nation's most important symbol of economic nationalism and anti-imperialism, the state petroleum company Yacimientos Petrolíferos Fiscales (YPF). Yuzhamtorg's sale price for oil was lower than the cost of gasoline production in Argentina and as Pueyrredón pitched the terms of the agreement, it became clear that the annual supply of 250 million litres that the Soviets planned to sell would have a damaging effect on the Argentine oil industry. In 1930, Argentina's domestic gasoline consumption was no more than 900 million litres. Pueyrredón tried in vain to defend the potential harm to YPF, asserting that the nationally owned oil fields could be maintained as a reserve for future use. No. 427, 'Special Measures of Argentine Government Against Dumping', H. Livingston Hartley, United States Vice-Consul in Buenos Aires, 12 August 1931, 635.006/1, RG 59, NA. 
79. Translation, Report of the diplomatic situation between the Argentine Republic and the Russian Soviet Government, sent by His Excellency the Minister of Foreign Affair and Worship, Doctor Angel Gallardo, to the Committee on Foreign Affairs of the Chamber of Deputies of the Nation, Buenos Aires, 31 August 1928 (Circular Informativo Mensual, No. 128 (agosto 1928), pp. 458-475.).

80. 'Dígase toda la verdad', La Prensa, 10 April 1928; 'Declaraciones del doctor Pueyrredón', La Prensa, 13 April 1928; Kellogg to Bliss, 5 March 1928, Reel 31, Kellogg Papers, LC. Despite Kellogg's complaints about newspaper coverage in other parts of the world, US press reports fell under the influence of Hughes's controlling diplomacy. The United States delegation chief staged press conferences every morning for which he took copious notes daily and at which he 'explained' the previous day's happenings to a press corps among whom only a handful spoke Spanish. In spite of Kellogg's displeasure, he remained satisfied with the allegiances of his Latin American allies at Havana. The State Department described Brazil, Peru, Costa Rica, and Nicaragua as very friendly to United States interests. Honduras voted consistently with the United States as did Venezuela, while Cuba was always prepared to 'jump into the fight' and Colombia 'came to battle for us'. See White to Bliss, 29 February 1928, White Papers, HHPL.

81. At Havana, the decision to postpone the problems of conciliation and arbitration of international disputes was taken by a different committee than that which adjourned the question of anti-intervention to Montevideo. Nevertheless, in the public atmosphere engendered by Pueyrredón and Guerrero, US policymakers combined the two related topics in their effort to dominate Pan Americanism at the Washington Conference on Conciliation and Arbitration.

82. See 'International Conference of American States on Conciliation and Arbitration, Held at Washington, December 10, 1928-January 5, 1929 : Conventions', FRUS, vol. 1, 1929 (Washington: Government Printing Office, 1943), pp. 653-669.

83. Hughes to Kellogg, 27 March 1928; Kellogg to Hughes, 19 March 1928, Reel 31, Kellogg Papers, LC.

84. Francis White, Memorandum, undated, White Papers, HHPL; 'Actuará Cuba de Mediadora en Argentina', El País (Habana), 1 December 1928; Podesta Costa to Horacio Oyhanarte, Minister of Foreign Affairs, 21 November 1928; Alcorta to Oyhanarte, 20 November 1928, Expediente 10, VI Conferencia Internacional Americana, Pol, MRE. 
85. Fletcher to Secretary of State, 9 December 1927, Reel 29, Kellogg Papers, LC; No. 885, Evan E. Young, United States Minister in the Dominican Republic, to Secretary of State, 11 May 1928, 710.1012 Washington/34; No. 955, Matthew E. Hanna, United States Chargé d'Affaires in Lima, to Secretary of State, 14 May 1928, 710.1012 Washington/36; No. 550, Kreeck to Secretary of State, 17 May 1928, 710.1012 Washington/68; No. 437, Bliss to Secretary of State, 5 December 1928, 710.1012 Washington P43/353, RG 59, NA.

86. 'Treaty to Avoid or Prevent Conflicts between the American States', FRUS, vol. 1, 1923, pp. 308-314.

87. Joseph W. Stinson, Drafting Officer, Department of State, to Francis White, Charles M. Barnes, Chief, Treaty Division, Department of State, and Benjamin Thaw, Jr., Assistant Chief, Division of Latin American Affairs, 24 July 1928, 710.1012/85; Walter C. Thurston, Secretary of the International Conference of American States on Conciliation and Arbitration, to Francis White, 25 July 1928, 710.1012/86, RG 59, NA; 'Memorandum for use before the Foreign Relations Committee', December 1928, Reel 36, Kellogg Papers, LC.

88. Conference rules imposed strict limitations on free speech: 'No delegation may, through any of its members, speak more than twice on the same subject, nor shall any delegation occupy the floor for more than 30 minutes at a time. Any delegate, however, shall have the right to speak for no more than 5 minutes upon a question of order or to answer any personal allusions or to explain his vote, and the author of a motion may speak once more, not exceeding 30 minutes'. In reference to the high drama of the final plenary session at Havana, new rules noted that 'the closing session of the Conference shall be devoted to the signing of those treaties, conventions, agreements, votes, resolutions and recommendations which have previously been approved by the conference'. See 'Proposed Rules for the International Conference of American States on Conciliation and Arbitration', nd, State Department Memorandum, White Papers, HHPL.

89. Ibid. 'Statement issued by the Mexican Ministry of Foreign Relations', El Universal, 6 February 1929, cited in No. 1406, Dwight W. Morrow, American Ambassador to Mexico, to Secretary of State, 5 February 1929, 710.1012 Washington/208, RG 59, NA. The principle of a multinational approach to conflict, as created in the broadened role of the commissions, would serve United States interests in future conflicts. This tenet allowed the United States to draw formally and publicly on its regional political friendships, in the way the State Department surreptitiously marshalled Latin American diplomatic backing in late 1927. This was demonstrated during and after the US-inspired 1954 coup d'état in Guatemala, when the United States sought international legitimacy for 
the new government through the petitions of Honduras and Nicaragua, within the Organization of American States. See Richard Immerman, The C.I.A. in Guatemala (Austin, TX: University of Texas Press, 1982).

90. Ibid.; J. Reuben Clark, Jr., Acting Secretary of State, to Charles Howland, 710.1012 Washington/260, RG 59, NA; 'First Lecture of Charles E. Hughes on the Sherrill Foundation at Yale University, New Haven, 22 March 1929'. White Papers, HHPL; Enrique Finot, Ex-delegate of Bolivia to the Commission of Investigation and Conciliation, Memorandum Confidencial sobre la actuación de los representantes neutrales a la Comisión de Investigación y Conciliación de 1929, Washington, 1932, unpublished; White to Stimson, 6 April 1929, White Papers, HHPL.

91. No. 496, J. C. White, United States Chargé d'Affaires in Buenos Aires, to Secretary of State, 13 March 1929, 710.1012 Washington/235, RG 59, NA.

92. 'Inspection Trips while stationed in Buenos Aires as Consul General', 1946, vol. I, no. 10, George S. Messersmith Papers, University of Delaware, Newark, Delaware.

93. George Jackson Eder, 'International Competition in the Trade of Argentina', International Conciliation No. 271, Studies in World Economy, 4 (June 1931), pp. 403-405; Gravil, The Anglo-Argentine Connection, pp. 161-162; G.H. Thompson, Foreign Office Memorandum, 7 June 1928, 12727, FO 371, PRO. Thompson's perspective on 'anti-United States sentiments' corresponded with other indications of the success of Hughes's Pan American diplomacy, and the failure of Pueyrredón to arouse popular anger against the United States. J.H.S. Birch, the British Counsellor in Rio de Janeiro, remarked that in Brazil, the approach of Carnival had turned the attention of the press and the public away from Pan Americanism and United States interventions in Central America. In addition, British representatives in Paraguay, Guatemala and Chile found that the impact of the Havana conference on popular perceptions had been negligible. See No. 41, Birch to Chamberlain, 2 March 1928; No.20, 29 March 1928, H.A.C. Cummins, British Consul to Paraguay, to Chamberlain; No.36, 17 March 1928, Harrington to Chamberlain; Memorandum, Oswald A. Scott, British First Secretary in Santiago, 17 April 1928, 12727, FO 371, PRO.

94. John Edwin Fagg, Pan Americanism (Malabar, FL: Robert E. Krieger Publishing, 1982), pp. 48-51; Peterson, Argentina, pp. 382-385; Caicedo Castilla, El Panamericanismo, pp. 130-132; J. Lloyd Mecham, The United States and Inter-American Security, 1889-1960 (Austin, TX: University of Texas Press, 1961), pp. 116-121; David Green, The Containment of Latin America: A history of the myths and realities of the Good Neighbor Policy (Chicago, IL: Quadrangle 
Books, 1971). In November 1930, after terms as ambassador to Denmark and the Netherlands, Felipe Espil was named Financial Adviser to the Argentine Embassy in Washington. The Argentine government appointed him Ambassador to the United States in 1932. Espil would hold that post until 1943, representing the longest ambassadorial term in Washington in Argentine history. 



\section{RESEARCH PAPERS}

No 1: Oil and Politics in Ecuador, 1972-1976 by George Philip (1978)

No 2: Industrial Investment in an 'Export' Economy: the Brazilian Experience before 1914 by Flávio Rabelo Versiani (1979)

No 3: Peruvian Labour and the Military Government since 1968 by Alan Angell (1980)

No 4: Labour in Chile under the Junta, 1973-1979 by Gonzalo Falabella (1981)

No 5: W.H. Hudson: the Colonial's Revenge. A Reading of his Fiction and his Relationship with Charles Darwin by Jason Wilson (1981)

No 6: Development Policymaking in Mexico: the Sistema Alimentario Mexicano (SAM) by Michael Redclift (1981)

No 7: Brazilian Private Industrial Enterprise, $1950-1980$ by Susan M. Cunningham (1982)

No 8: Bolivia 1980-1981: the Political System in Crisis by James Dunkerley (1982)

No 9: Paraguay in the 1970s: Continuity and Change in the Political Process by James Painter (1983)

No 10: Simón Bolivar and the Age of Revolution by John Lynch (1983)

No 11: The Crisis of the Chilean Socialist Party (PSCh) in 1979 by Carmelo Furci (1984)

No 12: Bonanza Development? The Selva Oil Industry in Peru, 19681982 by George Philip (1984)

No 13: The Retreat from Oil Nationalism in Ecuador, 1976-1983 by Christopher Brogan (1984)

No 14: Harnessing the Interior Vote: the Impact of Economic Change, Unbalanced Development and Authoritarianism on the Local Politics of Northeast Brazil by Scott William Hoefle (1985)

No 15: Caciques, Tribute and Migration in the Southern Andes: Indian Society and the 17th Century Colonial Order (Audencia de Charcas) by Thierry Saignes (1985)

No 16: The Market of Potosi at the End of the Eighteenth Century by Enrique Tandeter (1987)

No 17: Prostitution in Nineteenth-Century Rio de Janeiro by Luiz Carlos Soares (1988)

No 18: The State and Henequen Production in Yucatán, 1955-1980 by Roberto Escalante (1988)

No 19: The Mexican Landlord: Rental Housing in Guadalajara and Puebla by Alan Gilbert and Ann Varley (1989) 
No 20: Roraima: Brazil's Northernmost Frontier by John Hemming (1990)

No 21: The Speaking of History: 'Willapaakushayki', or Quechua Ways of Telling the Past by Rosaleen Howard-Malverde (1990)

No 22: Political Transition and Economic Stabilisation: Bolivia, 19821989 by James Dunkerley

No 23: The New Agrarian Movement in Mexico 1979-1990 by Neil Harvey (1991)

No 24: The Idea of the Devil and the Problem of the Indian: the case of Mexico in the sixteenth century by Fernando Cervanies (1991)

No 25: Argentina and the United States at the Sixth Pan American Conference (Havana 1928) by David Sheinin (1991)

No 26: Public Policy and Private Initiative: Railway Building in São Paulo, 1860-1889 by Colin Lewis (1991)

No 27: A Long-Run Model of Development for Latin America by Victor Bulmer-Thomas (forthcoming 1991)

No 28: The Red and the Black. The Sandinistas and the Nicaraguan Revolution by Elizabeth Dore and John Weeks (forthcoming 1991) 


\section{EUROPEAN IMMIGRATION AND ETHNICITY IN LATIN AMERICA}

\section{A BIBLIOGRAPHY}

\section{Compiled by Oliver Marshall}

An extensive bibliography including more than 1450 publications - books, articles in books and journals, working papers and conference proceedings - relating to European immigration and ethnicity in Latin America since 1800. The main focus is on immigrants arriving in Latin America directly from Europe, classified according to their national and ethnic backgrounds. (Latin America here covers the former Spanish and Portuguese territories in the Americas and also Haiti and Belize.)

The bibliography includes materials published since about 1960 in all European languages. It complements and extends the scope of existing resources such as Juan Bailey and Freya Headlam, Intercontinental Migration to Latin America: a select bibliography (London: Institute of Latin American Studies, 1980).

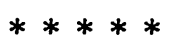

A valuable addition to the bibliographical sources available to researchers on Latin America.

ISBN 0901145726

$£ 10.00 \mathrm{UK} /$ Europe $£ 13.50$ Overseas (US $\$ 25.00$ ) 


\title{
AN A TO Z OF LATIN AMERICAN LITERATURE IN ENGLISH TRANSLATION
}

\author{
Compiled by Jason Wilson
}

"Say what you will of its inadequacy, translation remains one of the most important, worthwhile concerns in the totality of world affairs."

Goethe to Carlisle

The $A$ to $Z$ is a checklist and guide to the fiction, theatre and poetry (and some essays and memoirs) of the Spanish and Portuguese speaking New World since Independence: 650 published translations of works by 256 authors, from Agosín to Zurita, with an appendix of 118 Anthologies and a Bibliography of sources.

This will be a useful bibliographical tool for scholars and librarians and will give the student of comparative literature and the general reader access to the rich and important field of Latin American Literature.

\section{About the author}

Jason Wilson is Lecturer in Latin American Literature at University College London. He has published two books on Octavio Paz, and essays and reviews on Latin American literature and culture. Special interests include the translation of Alexander von Humboldt's Travels.

ISBN $090114567 \mathrm{X}$

$£ 5.50$ UK $£ 7.50$ Overseas (US\$13.50). 


\section{INSTITUTE OF LATIN AMERICAN STUDIES}

University of London

Publications of the Institute:

Institute of Latin American Studies Monographs

(14 titles in print)

$\star \star \star$

Research Papers

$\star \star \star \star$

Bibliographies, source lists and other guides

$\star \star \star$

Handbooks on Latin American Studies and Research on Latin America in the Humanities and Social Sciences in the Universities and Polytechnics of the United Kingdom, giving details of recent publications and theses completed and in progress.

Full details and prices are given in the Publications List available from the Institute.

Institute of Latin American Studies

31 Tavistock Square

London WC1H 9HA

Telephone: 071-387 5671

Fax: 071-388 5024 


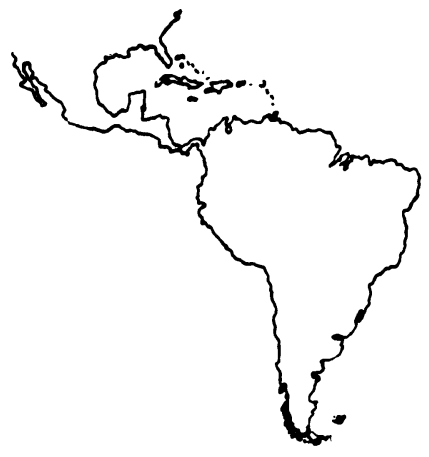

Papers in this series may be obtained from the INSTITUTE OF LATIN AMERICAN STUDIES

31, Tavistock Square, London WC1H 9HA

Price per copy, including postage:

Vols $1-20$

United Kingdom and Europe $£ 3.50$, Overseas (airmail) $£ 5.00$ (US \$11.50)

Vols 21-

United Kingdom and Europe $£ 4.50$, Overseas (airmail) $€ 7.00$ (US \$14.00)

Please make cheques payable to The University of London 
